\title{
POLA ASUH ANAK ETNIK TAMIANG
}

\author{
Roro Sri Hariyani \\ Kepala SMKN 3 Karang Baru Aceh Tamiang \\ rorosriharyani12@gmail.com
}

\begin{abstract}
Abstrak
Artikel yang merupakan hasil dari penelitian desertasi ini bertujuan untuk mengetahui bagaimana pola asuh anak etnik Tamiang di Kabupaten Aceh Tamiang. Adapun populasi dalam penelitian ini yaitu penduduk desa sekerak kanan kecamatan Sekerak dan dan desa Paya Udang kecamatan seruwei. Sedangkan sampel dalam penelitian yaitu penduduk etnik Tamiang yang ada di desa Sekerak kanan dan Paya Udang. Penelitian ini merupakan penelitian kualitatif. Data dikumpulkan dengan menggunakan teknik observasi langsung, wawancara, serta studi literatur. Tujuan penelitian ini ingin menguraikan suatu kebiasaan yang menjadi pola dalam sistem pengasuhan anak pada etnik Tamiang dan melihat perubahan-perubahan yang terjadi yang diakibatkan oleh beberapa faktor yang melatarbelakanginya. Selanjutnya mengungkapkan berbagai resistensi yang dilakukan sebagai upaya untuk mempertahankan adat istiadat dan tata nilai dalam kebudayaan etnik Tamiang yang berhubungan dengan pengasuhan anak. Dari penelitian ini, diperoleh hasil bahwa kelompok etnik Tamiang menjalankan suatu pola pengasuhan secara tradisional yang meliputi: masa kehamilan, kelahiran, dan sampai proses pembesaran anak-anak. Kelompok ini memiliki cara-cara tersendiri dalam mengasuh anak mereka mulai dari membedung, mendodoi, serta menabalkan nama. Anak-anak etnik Tamiang juga diajarkan untuk menerapkan sikap menghormati dan menghargai orang yang lebih tua dengan cara menggunakan istilah penyebutan menurut tingkat kelahiran mereka. Kebiasaan ini mengekspresikan suatu identitas budaya etnik Tamiang yang masih dipertahankan sampai saat ini. Dari hasil penelitian juga ditemukan beberapa perubahan dalam pengasuhan anak-anak pada orang etnik Tamiang. Hal ini dikarenakan adanya perbedaan pola pikir. Meskipun demikian, sebagian dari kelompok etnik Tamiang masih melakukan resistensi sebagai upaya untuk mempertahankan tata nilai dan pola asuh menurut adat istiadat etnik Tamiang.
\end{abstract}

Kata Kunci: Sistem Pengasuhan, Resistensi, Tata Nilai, Pola Pikir

\section{PENDAHULUAN}

Hakikat manusia sejak terbentuknya manusia baru yakni sejak terjadinya konsepsi antara sel telur dengan sperma sampai menjadi tua akan mengalami suatu perkembangan. Hanya dalam kualitas dan sifat perkembangan ini akan mengalami perbedaan-perbedaan sesuai dengan fase-fasenya. Demikian juga dengan hakikat dalam perkembangan manusia selalu membutuhkan orang lain. Anak membutuhkan orang lain yang akan membantu perkembangan keseluruhan dirinya, sekalipun anak juga tergantung pada fase perkembangannya. Artinya, ada fase dimana anak tergantung sepenuhnya pada orang lain, misalnya bayi yang baru lahir. Sebaliknya, ada fase dimana anak dapat melepaskan sebagian besar ketergantungannya, misalnya anak usia 17 tahun yang menginjak kedewasaannya.

Tanpa orang lain yang membantu perkembangan anak, maka anak mungkin masih dapat mengembangkan sesuatu dari dirinya, dari kecil tumbuh menjadi tinggibesar, namun satu hal yang tidak dapat dipungkiri bahwa anak yang berkembang tanpa bantuan manusia lainnya akan kehilangan hakikat kemanusiaan dan kesosialannya. Untuk dapat memahami dan dapat bergaul dengan orang lain inilah dibutuhkan keahlian, keahlian itu ada dalam pola pendidikan life skills education. Dalam pola pendidikan ini anak bukan hanya diajarkan tentang makna dan kemampuan untuk bertahan hidup dengan satu kemampuan unggulan yang dimilikinya akan tetapi dalam life skills education ini anak juga dilatih untuk mampu hidup bersosial dengan berkolaborasi dengan lingkungannya dengan baik sehingga kemampuan itu merupakan kemampuan yang bersifat integral dalam kecakapan hidup bersosial. Anak ternyata membutuhkan orang lain dalam perkembangannya dan orang yang paling dan pertama bertanggung jawab adalah orangtua. Orangtua dan lingkunganlah yang bertanggung jawab memperkembangkan keseluruhan eksistensi anak.

Pada dasarnya, orangtua selalu mendidik anakanak mereka, baik sejak dalam kandungan maupun setelah lahir dalam bentuk-bentuk pembelajaran dan pendidikan yang sederhana. Apa yang diperoleh dari orangtua akan menjadi pengalaman awal anak yang akan mempengaruhi kepribadian anak selanjutnya. merujuk dari teori John Loke yaitu "empirisme”, bahwa manusia lahir bagikan kertas putih, akan menjadi apa anak tersebut dikemudian hari, akan sangat tergantung dari apa yang dituliskan di atasnya, artinya pengalaman apa yang didapatkan anak termasuk faktor pendidikan dan pola asuh orangtua menjadi bahan tulisan yang akan mewarnai 
kehidupan ataupun kualitas diri anak tersebut, dan yang paling mewarnai dari tulisan tersebut adalah tulisan yang pertama dilakukan oleh orangtuanya. Sejalan dengan pendapat Freud yang menyatakan bahwa kepribadian sebenarnya telah terbentuk pada akhir tahun kelima dan perkembangan selanjutnya sebagian besar hanya merupakan penghalusan struktur dasar itu (Suryabrata, 1993).

Pembentukan karakter dan kepribadian anak erat kaitannya dengan pengaruh pola asuh yang diterapkan. Setiap orang, kelompok, maupun etnik tertentu memiliki pola asuh anak sendiri. Pola-pola asuh tersebut menjadikan masing-masing individu menjadi pribadi yang utuh sebagai anggota masyarakat. Pola asuh tersebut berbeda di setiap kebanyakan etnik. Perbedaan tersebut merupakan implikasi dari perbedaan pola hidup setiap etnik tersebut. Dengan kata lain, perbedaan pola hidup, cara pandang, sistem budaya yang berlaku merupakan faktor yang mewarnai perbedaan itu.

Pada dasarnya, pola asuh merupakan interaksi antara anak dan orang tua selama mengadakan kegiatan pengasuhan. Pengasuhan berarti orang tua mendidik, membimbing dan mendisiplinkan serta melindungi anak untuk mencapai tingkat kedewasaan sesuai dengan norma-norma yang ada dalam masyarakat. Dengan demikian pola asuh dapat diartikan sebagai suatu cara yang di pakai atau di terapkan dalam menjaga, merawat, dan mendidik anak agar dapat berdiri sendiri.

Pola asuh orang tua erat hubungannya dengan kepribadian anak setelah ia menjadi dewasa. Hal ini di sebabkan ciri-ciri dan unsur-unsur watak seorang individu dewasa sebenarnya sudah diletakkan benihbenihnya ke dalam jiwa seorang individu sejak awal, yaitu pada masa ia masih kanak-kanak. Watak ditentukan oleh pola asuh sejak kecil, seperti diajarkan makan, diajar kebersihan, disiplin, diajar bermain dan bergaul dengan anak lain dan sebagainya (Koentjaraningrat, 1997).

Setiap bangsa punya cara unik dan khas dalam hal pengasuhan anak karena memang pola asuh anak erat kaitannya dengan budaya setempat. Orangtua berkebangsaan China yang membesarkan anaknya di Amerika, bagaimanapun, akan dipengaruhi latar belakang budaya masyarakat China. Sebuah esai di Wall Street Journal menuliskan pola pengasuhan keluarga China cenderung keras tetapi tetap menunjukkan cintanya. Mentalitas masyarakat China yang pantang menyerah juga terlihat dalam pola asuh. Penulis esai tersebut mengatakan, orangtua tidak akan sungkan memberikan hukuman jika anaknya mendapatkan nilai A minus. Mereka cenderung menggembleng anak-anak dengan keras. Tujuannya agar anak berusaha sekuat tenaga mencapai hasil maksimal. Saat anak menunjukkan sikap tidak menghargai orangtua, anak-anak harus bersiap menerima omelan atau kritik tajam dari orangtuanya. (Kompas: 2011)

Keyakinan budaya setempat juga akan mempengaruhi pola pengasuhan anak. Seorang ibu di Brazil yang hidup di permukiman kumuh yang disiang hari meninggalkan tiga balitanya dalam ruangan gelap untuk mencari makan dan pakaian, mungkin ini terlihat kejam dari sudut pandang buaya lain. Akan tetapi, demikianlah budaya yang ada di sana. Di Cina ada praktik dimana bayi-bayi yang masih berusia beberapa minggu ditinggal ibunya untuk pergi berladang dalam jangka waktu yang cukup lama. Bayi-bayi tersebut dibaringkan di sak-sak pasir yang lebar dan menyokong tubuh mereka sekaligus bertindak sebagai popok penyerap. Tak butuh waktu yang lama untuk bayi berhenti menangis karena menyadari bahwa tindakannya itu tidak menghasilkan respon apapun. (http://wordpress.com: 2011).

Ada beberapa faktor yang mempengaruhi perbedaan pola asuh anak yang antara lain;

1. Perbedaan budaya

Budaya antara Negara atau daerah mempunyai polapola yang berbeda dalam hal mendidik dan mengasuh anak. Misalnya budaya jawa, antara anak dan orang tua memiliki jarak. Bentuk perhatian orang tua terhadap tidak diungkapkan secara verbal.

2. Perbedaan kebiasaan

Setiap daerah memiliki kebiasaan yang berbeda dalam menghadapi dan mengasuh anak. Misalnya kebiasaan makan. Dalam suatu keluarga tertentu ada kebiasaan bahwa jam makan malam adalah kegiatan dimana semua keluarga harus berkumpul dan makan bersama.

3. Perbedaan kepercayaan

Perbedaan kepercayaan yaitu perbedaan dalam hal keyakinan dan agama suatu keluarga tertentu yang hal ini dapat memberikan pengaruh terhadap pola asuh anak.

4. Kepribadian orang tua.

Perbedaan ini didasarkan pada karakter orang tua itu sendiri yang berperan besar dalam pola pengasuhan anak. (Anneahira. 2011. Tentang Balita, (online) http//www/: anneahira.com.htm)

Namun demikian, dalam hal pola asuh anak, maka keluarga memiliki peran yang besar dalam mendidik anak. Hal ini senada dengan apa yang ditegaskan Singgih bahwa keluarga adalah unit/satuan masyarat terkecil yang sekaligus merupakan suatu kelompok kecil dalam masyarakat yang hubungannya dengan perkembangan individu (Singgih, 1981). Keluarga inilah yang melahirkan individu-individu dengan berbagai macam bentuk kepribadiannya dalam masyarakat. Tidak dapat dipungkiri bahwa sebenarnya keluarga mempunyai fungsi yang tidak hanya terbatas untuk memperoleh keturunan saja. Hal ini juga sejalan dengan pendapat Darmanyah 
bahwa keluarga secara ideal tidak hanya sekedar penerus keturunan tetapi lebih jauh adalah sebagai sumber pendidikan utama yang sekaligus menjadi produsen dan konsumen (Darmanyah, 1986). Artinya keluargalah yang bertanggungjawab atas tersedianya kebutuhan organik maupun kebutuhan psikologis baik untuk keluarga kecilnya maupun dalam jangka panjang untuk memenuhi kebutuhan masyarakat.

Sebagaimana disebutkan di atas, bahwa agama juga memiliki pengaruh dalam menentukan pendidikan dan pola pengasuhan anak. Demikian juga bagi etnis Tamiang, sehingga ada pepatah yang memasyarakat "Belum tumbuh gigi udah baca kitab", anak-anak etnik Tamiang di Aceh Tamiang dari kecil sudah dibiasakan untuk mengenal agama Islam dan membaca Alquran. Sejalan dengan pendapat Muntasir yang menyatakan bahwa etnik Tamiang dalam perilaku kehidupannya memiliki keterkaitan yang erat dengan adat istiadat yang sejalan dengan nilai-nilai agama. Dalam melaksanakan adat tetap berpegang pada ajaran agama, sehingga setiap menetapkan aturan adat tetap mengacu pada ketentuan agama yaitu agama Islam, karena masyarakat etnis Tamiang seluruhnya beragama Islam, kebiasaan adat dijalin dan hukum diatur dalam suatu musyawarah (Muntasir, 2003).

Hal di atas sejalan dengan pandangan yang mengatakan bahan pengalaman yang diterima anak-anak ini ditentukan oleh susunan dari lingkungan tempat kanak-kanak tadi tumbuh, sedangkan susunan lingkungan itu tentu mendapat pengaruh dari masyarakat dan kebudayaan (Koentjaraningrat, 1961).

Bagi etnik Tamiang, adat dan hukum adat merupakan salah satu "alat petunjuk arah" yang ampuh untuk menentukan sikap dan tingkah laku dalam pergaulan sehari-hari, sesuai dengan ungkapan "Urang cadek adat macam kapai cadek kemudi"(orang yang tidak punya adat seperti kapal tidak punya nakhoda). Sehingga orang akan selalu bersikap dan bertingkah laku dalam batas-batas yang telah dibenarkan oleh adat dan hukum adat, seperti ungkapan "Tande belang ade batehnye, tande antagre pagar".Yang berarti segala sesuatu itu mempunyai aturan dan batas-batas wewenang tertentu (Muntasir, 2003).

Dari hal diatas penulis tertarik untuk meneliti lebih lanjut pola asuh anak etnik Aceh Tamiang yang dituangkan dalam judul "POLA ASUH ANAK ETNIK TAMIANG".

Adapun permasalahan dalam penelitian ini dirumuskan sebagai berikut :

1. Bagaimana pola asuh anak etnik Tamiang?

2. Faktor-faktor apa yang mempengaruhi pola asuh anak etnik Tamiang?
3. Apakah faktor-faktor resistensi yang dapat mempertahankan pola asuh anak etnik Tamiang secara tradisional?

Pola asuh terdiri dari dua kata yaitu pola dan asuh. Dalam Kamus Besar Bahasa Indonesia (1988: 54) pola berarti corak, model, sistem, cara kerja, bentuk (struktur) yang tetap, sedangkan kata asuh dapat berarti menjaga (merawat dan mendidik) anak kecil, membimbing (membantu; melatih dan sebagainya), dan memimpin (mengepalai dan menyelenggarakan) satu badan atau lembaga. Lebih jelasnya, kata asuh adalah mencakup segala aspek yang berkaitan dengan pemeliharaan, perawatan, dukungan, dan bantuan sehingga orang tetap berdiri dan menjalani hidupnya secara sehat.

Menurut Ahmad Tafsir seperti yang dikutip oleh Irwanto (1991: 94) Pola asuh berarti pendidikan, sedangkan pendidikan adalah bimbingan secara sadar oleh pendidik terhadap perkembangan jasmani dan rohani anak didik menuju terbentuknya kepribadian yang utama. Jadi pola asuh adalah suatu keseluruhan interaksi antara orang tua dengan anak, di mana orang tua bermaksud menstimulasi anaknya dengan mengubah tingkah laku, pengetahuan serta nilai-nilai yang dianggap paling tepat oleh orang tua, agar anak dapat mandiri, tumbuh dan berkembang secara sehat dan optimal.

Dengan demikian, pola asuh dapat diartikan seluruh cara perlakuan orang tua yang diterapkan pada anak. Banyak ahli yang mengatakan pengasuhan anak adalah bagian penting dan mendasar, menyiapkan anak untuk menjadi masyarakat yang baik. Terlihat bahwa pengasuhan anak menunjuk kepada pendidikan umum yang diterapkan. Pengasuhan terhadap anak berupa suatu proses interaksi antara orang tua dengan anak. Interaksi tersebut mencakup perawatan seperti dari mencukupi kebutuhan makan, mendorong keberhasilan dan melindungi, maupun mensosialisasikan yaitu mengajarkan tingkah laku umum yang diterima oleh masyarakat.

Bentuk pola asuh orang tua sangat erat hubungannya dengan kepribadian anak setelah ia menjadi dewasa. Hal ini di karenakan ciri-ciri dan unsur-unsur watak seorang individu dewasa sudah diletakkan benihbenihnya ke dalam jiwa seorang individu sejak sangat awal, yaitu pada saat ia masih kanak-kanak. Hal ini ditentukan oleh kebiasaan-kebiasaan yang dilakukan waktu kecil diajarkan makan, kebersihan, disiplin, diajar main dan bergaul dengan orang lain dan sebagainya. Dalam pengasuhan anak terkandung pola pendidikan, sopan santun, membentuk latihan-latihan, tanggung jawab dan sebagainya. Dalam hal ini tentunya peran orang tua sangat penting, karena langsung menentukan sikap anak serta tindakkannya kemudian hari.

Dalam Martin (1997: 43) disebutkan ada beberapa tipe pola asuh anak yaitu;

1. Pola asuh permisif; Pola asuh permisif adalah jenis pola mengasuh anak yang cuek terhadap anak. Jadi apa pun yang mau dilakukan anak diperbolehkan seperti tidak sekolah, bandel, melakukan banyak kegiatan maksiat, pergaulan bebas negatif, 
matrialistis, dan sebagainya. Biasanya pola pengasuhan anak oleh orangtua semacam ini diakibatkan oleh orangtua yang terlalu sibuk dengan pekerjaan, kesibukan atau urusan lain yang akhirnya lupa untuk mendidik dan mengasuh anak dengan baik. Dengan begitu anak hanya diberi materi atau harta saja dan terserah anak itu mau tumbuh dan berkembang menjadi apa. Anak yang diasuh orangtuanya dengan metode semacam ini nantinya bisa berkembang menjadi anak yang kurang perhatian, merasa tidak berarti, rendah diri, nakal, memiliki kemampuan sosialisasi yang buruk, kontrol diri buruk, salah bergaul, kurang menghargai orang lain, dan lain sebagainya baik ketika kecil maupun sudah dewasa.

2. Pola asuh otoriter; Pola asuh otoriter adalah pola pengasuhan anak yang bersifat pemaksaan, keras dan kaku di mana orangtua akan membuat berbagai aturan yang saklek harus dipatuhi oleh anak-anaknya tanpa mau tahu perasaan sang anak. Orang tua akan emosi dan marah jika anak melakukan hal yang tidak sesuai dengan yang diinginkan oleh orang tuanya. Hukuman mental dan fisik akan sering diterima oleh anak-anak dengan alasan agar anak terus tetap patuh dan disiplin serta menghormati orang-tua yang telah membesarkannya. Anak yang besar dengan teknik asuhan anak seperti ini biasanya tidak bahagia, paranoid/selalu berada dalam ketakutan, mudah sedih dan tertekan, senang berada di luar rumah, benci orangtua, dan lain-lain, tetapi di balik itu biasanya anak hasil didikan ortu otoriter lebih bisa mandiri, bisa menjadi orang sesuai keinginan orang tua, lebih disiplin dan lebih bertanggungjawab dalam menjalani hidup.

3. Pola asuh otoritatif; Pola asuh otoritatif adalah pola asuh orangtua pada anak yang memberi kebebasan pada anak untuk berkreasi dan mengeksplorasi berbagai hal sesuai dengan kemampuan anak dengan sensor batasan dan pengawasan yang baik dari orangtua. Pola asuh ini adalah pola asuh yang cocok dan baik untuk diterapkan para orangtua kepada anakanaknya. Anak yang diasuh dengan tehnik asuhan otoritatif akan hidup ceria, menyenangkan, kreatif, cerdas, percaya diri, terbuka pada orangtua, menghargai dan menghormati orangtua, tidak mudah stres dan depresi, berprestasi baik, disukai lingkungan dan masyarakat dan lain-lain.

\section{Pola Asuh Anak}

Dalam kamus umum bahasa Indonesia edisi (2007: 42) disebutkan bahwa anak itu dikelompokkan menjadi tiga golongan, yaitu anak kandung atau anak dari darah daging sendiri. Anak angkat, yaitu anak yang bukan berasal dari keturunan asli atau anak orang lain yang diangkat dan diasuh sebagaimana anak sendiri. Sedangkan anak tiri, adalah anak yang bukan anak kandung (anak bawaan suami atau isteri).

Pada umumnya, laki-laki atau perempuan baranggapan bahwa anak adalah karunia terbesar, harta yang paling berharga, cita-cita yang tinggi, serta belahan jiwa yang secara khusus diberikan oleh Tuhan Yang
Maha Kuasa kepada manusia yang telah menantinantikan kehadirannya. Menurut kajian ilmu Biologi, anak adalah hasil dari suatu proses tahapan yang bermula dari bertemunya sel kelamin jantan dan betina (pembuahan), lalu terbentuklah zigot yang bergerak ke uterus hingga terbentuklah embrio yang akan tumbuh menjadi janin. Janin tersebut akan tumbuh dan jika saatnya telah tiba maka akan lahir kedunia menjadi seorang anak.

Dalam agama islam disebutkan bahwa yang dinamakan anak adalah amanah Allah SWT yang harus dirawat, diasuh dan dipelihara hingga tumbuh menjadi dewasa. Sebelum anak tersebut dilahirkan kedunia, ia telah diberi ketetapan oleh Allah yaitu meliputi 3 perkara antara lain umur, rizki dan jodoh. Supaya anak mampu mencapai kesempurnaan tersebut, maka Allah SWT memberi tugas kepada orang tuanya untuk membimbing anaknya dengan baik dan benar agar tidak menyimpang dari jalan ajaran-Nya.

Orang tua merupakan model bagi perilaku anakanaknya. Orang tua dapat membentuk perilaku remaja dengan cara memberi contoh melalui perilakunya, mendorong anak untuk berbuat sesuatu yang baik, menunjukkan kepada remajanya bagaimana cara bertindak berkenaan dengan pola asuh orang tua yang terjadi dan salah satunya akan terlihat dalam suatu keluarga.

Setiap anak (bayi) yang baru dilahirkan memiliki nuansa dan pesona tersendiri. Begitulah besarnya karunia Allah Swt, sehingga setiap anak harus dijaga dan di didik dengan penuh kasih sayang. Pada dasarnya dari sejak dalam kandungan secara tidak langsung anak itu sudah diberikan pendidikan serta kasih dan sayang oleh kedua orang tua dan lingkungan masyarakatnya.

Dalam berbagai kehidupan etnis, salah satu diantaranya adalah etnis Melayu yang berdiam di wilayah Propinsi Aceh. Mereka disebut Etnik Aceh Tamiang. Mereka mendiami daerah paling ujung timur dari Propinsi Nanggroe Aceh Darussalam. Berbagai etnis memiliki adat istiadat baik dalam kehidupan bermasyarakat dan khususnya dalam aspek kelahiran. Demikian juga dengan etnis Tamiang memiliki adat istiadat dalam kelahiran. Menurut Wan Syarifuddin dan OK Syahril (2008:1) adat kelahiran di etnik Tamiang itu terdiri atas, sewaktu mengandung, bersalin dan sehabis melahirkan.

Dari hasil penelitian Ichwan Azhari (1984) di Desa Tapak Kuda tentang sosialisasi anak Melayu di pantai Timur Sumatera menemukan bahwa pola asuh yang di terapkan di desa tersebut adalah membedung, menyusui, makanan tambahan dan menyapih, mendodoi serta turun ke air dan belajar berjalan.

Lebih umum lagi di kemukakan oleh Muhammad Salleh Lamry (1996:37) pola asuh anak dilakukan sejak dalam kandungan, lingkungan sosial bayi sudah diarahkan kepada hal yang membentuk akhlaknya, misalnya sang ayah tidak boleh bertingkah laku kasar dan membunuh makhluk hidup.

Pandangan yang dikemukakan oleh para ahli di atas menunjukkan bentuk-bentuk atau cara mengasuh anak, dimulai sejak dalam kandungan sampai dilahirkan 
sampai anak itu mulai turun tanah dan berjalan. Bahkan ada pola asuh yang menunjukkan faktor luar yang dapat mempengaruhi anak walaupun masih dalam kandungan.

Kondisi di atas memberikan informasi yang sekaligus menjadi pengalaman bagi orang tua untuk mendidik anak-anaknya. Harus penuh dengan kehatihatian dan kasih sayang, bahkan perhatian yang penuh dan serius harus diberikan kepada anak. Sehingga anak akan tumbuh dengan penuh kasih sayang pula. Karena anak yang dididik dengan kasih sayang, maka ia akan belajar untuk membiasakan kasih sayang pula. Agar apa yang diharapkan orang tua terhadap anak-anaknya dapat terwujud dengan baik, maka orang tua dalam menerapkan pola asuh harus memahami metode-metode dalam mengasuh anak.

Menurut John W. M. Whiting Irvin L Child dkk (Danandjaja, 1989) menyatakan bahwa ada 10 metode pengasuhan anak adalah:

1. Tingkah laku yang bersifat selalu minta dilayani (succourance)

Metode ini merupakan bagian dari pola asuh orang tua kepada anak-anaknya, dimana orang tua harus mampu memahami perilaku anak yang kecenderungannya sifat anak itu selalu minta untuk dilayani, dipenuhi keinginannya. Jika tidak si anak akan melakukan perilaku yang agresif, keras dan bertahan untuk mendapatkan apa yang diinginkannya. Jika hal itu dipahami orang tua, tentu saja orang tua akan arif untuk menentukan perilaku yang bijak kepada anak-anaknya.

2. Tingkah laku yang bersifat suka mengungkapkan perasaan (expressiveness).

Metode ini mengedepankan nilai-nilai perasaan. Rasa emosional menjadi faktor yang dominan untuk digunakan dalam mengasuh anak-anaknya. Memberikan pembelajaran dan pendidikan melalui penanaman nilai-nilai perasaan yang lebih positif kepada anak-anaknya, dan senantiasa menampilkan dan mengungkapkan rasa perasaan dalam setiap aktivitas pengasuhnya.

3. Tingkah laku yang bersifat suka bergantung pada kemampuan diri sendiri (self reliance).

Metode ini mengutamakan kemampuan diri sendiri dan kemampuan ini dijadikan prioritas penentu dalam menerapkan pola asuhannya. Segala sesuatunya selalu merujuk pada kemampuan diri sendiri. Khawatir jika dalam mengasuh anak itu diberikan kepada orang lain. Walaupun orang itu keluarga dekatnya. Hal ini menunjukkan bahwa orang lain itu bukan orang yang paling utama dalam mengasuh anaknya. Berarti metode ini lebih mengedepankan kepercayaan pada diri sendiri dari pada orang lain.

4. Tingkah laku yang bersifat mempunyai rasa tanggung jawab (responsibility)

Metode ini mengunggulkan sifat untuk menyelesaikan pekerjaan yang menjadi tugas pokoknya. Melakukan aktifitas sesuai dengan semestinya, tidak melakukan pekerjaannya berdasarkan kesenangan saja tanpa prosedur atau norma-norma yang ada dalam melakukan pola asuh terhadap anak, sehingga pekerjaan itu selesai sesuai dengan norma-norma yang berlaku. Dengan demikian optimalisasi dalam menanamkan normanorma pola asuh sesuai dengan tanggung jawab terhadap apa yang dilakukannya.

5. Tingkah laku yang bersifat ingin mencapai sesuatu yang lebih baik (achievement-oriented behavior)

Metode ini menunjukkan bahwa perilaku yang ditampilkan lebih menonjol prestasi yang terbaik. Metode ini mengajarkan untuk senantiasa membudayakan prioritas yang lebih baik. Memberikan pola asuh tersebut dengan memberikan contoh-contoh sifat yang berupaya untuk mendapatkan yang terbaik dari yang lainnya. Berorientasi kepada perilaku yang lebih baik.

6. Tingkah laku yang bersifat patuh pada orang tua atau pemimpin (obidience)

Metode ini mengajarkan kepada anak agar memahami posisi kehidupan dalam keluarga, memahami siapa yang harus di hormati dan disayangi dan siapa pula yang memiliki hak untuk mengayomi, memelihara, melindungi dan memberikan kasih sayang dan perhatian. Sehingga dengan posisi kedudukan ini memudahkan untuk menerapkan pola asuh kepada anak-anaknya. Karena dipahaminya siapa yang harus disayanginya dan di hormatinya. Selain itu metode ini menunjukkan siapa diantara keluarga itu lebih banyak mempengaruhi untuk dapat mencapai tujuan kehidupan keluarga. Berarti memahami siapa yang menjadi pemimpin dalam keluarga tersebut. Itu artinya orang tua lah yang harus diperhatikan perilakunya dalam memberikan pola asuh kepada anak-anaknya.

7. Tingkah laku yang bersifat gemar menolong orang lain yang sedang mengalami kesukaran (nurture).

Metode ini mengajarkan untuk memiliki sifat perhatian kepada orang lain (Emphaty). Memahami apa yang dirasakan oleh orang lain, sehingga mendorong orang tersebut untuk membantu orang yang mengalami kesulitan.

8. Tingkah laku yang ingin menguasai orang lain (dominance).

Metode ini juga merupakan cara yang mengajarkan kepada kita untuk mampu mengendalikan dan memberikan anjuran kepada orang lain agar dapat mengikuti apa yang ia perintahkan. Metode ini dominan untuk dapat menguasain orang lain.

9. Tingkah laku yang bersifat keramahan didalam lingkungan pergaulan (sociability)

Metode ini merupakan salah satu metode mengasuh anak yang lebih menunjukkan sifat yang elegan dan peduli. Mengajarkan untuk senantiasa memberikan perhatian kepada siapapun yang membutuhkannya.

10. Tingkah laku yang bersifat suka menyerang (aggression), baik bersifat sebagai akibat ancaman dari luar (threat aggression), maupun yang bersifat menurut kesempatan (opportunity aggression).

Hal di atas dapat terjadi, manakala pola asuh orang tua terhadap anaknya menjadi pola yang rutin dan 
membudaya. Untuk itu orang tua harus memahami benar situasi dan kondisi si anak, tatkala orang tua akan melakukan proses pendidikan kepada anak. Artinya situasi harus dipelajari untuk menentukan pola asuh yang bagaimana yang relevan dengan kondisi anak tersebut. Semua itu menjadi bahan pengalaman bagi anak yang akan menjadi referensi perilaku sampai anak itu dewasa. Berarti perilaku anak akan terbentuk oleh pengalamanpengalaman yang didapatkan pada waktu anak masih kecil. Sebagaimana dikemukakan oleh Koentjaraningrat (Koentjaraningrat, 1961) berikut:

Bahan pengalaman yang diterima oleh anak-anak itu ditentukan oleh susunan dari lingkungan tempat kanak-kanak tadi tumbuh sedangkan susunan lingkungan itu tentu mendapat pengaruh dari pada masyarakat dan kebudayaan. Demikianlah apabila si penyelidik dapat mempelajari bagaimana susunan hidup dari pada kanak-kanak di dalam suatu masyarakat maka ia akan mendapat keterangan tentang tabiat utama dari pada individu-individu dewasa di dalam masyarakat oleh penyelidik itu.

Dari pernyataan ini dapat dipahami bahwa orang tua harus mengerti dan mempelajari terlebih dahulu kondisi-kondisi dan situasi-situasi yang berlangsung di sekitar lingkungan anak sebelum menerapkan pola asuh terhadap anak.

Selanjutnya menurut Hildred (1983), pengalaman masa kanak-kanak merupakan bentuk fundamental oleh bangunan kelembagaan di dalam keluarga dan dengan melalui pengalaman seperti itulah dia memperoleh pengertian tentang ikatan-ikatan moral yang menantinya memungkinkan dia bertindak selaku anggota dewasa dalam masyarakat.

Pendapat di atas sejalan dengan hasil penelitian yang dilakukan oleh Clora Dubois menjelaskaan bahwa sifat kepribadian orang Alor. Dimana anak-anak di Alor diliputi oleh rasa kesunyian dan tidak memiliki daya kreatif sebagai akibat kelalaian pihak ibu sewaktu anakanak masih kecil. Dalam masyarakat Alor disebutkan bahwa ibulah yang memegang peran utama dalam mencari nafkah di ladang sehingga tidak punya kesempatan untuk mengasuh anak. Anak-anak Alor sejak kecil telah diserahkan ibunya kepada saudara-saudara anak tersebut yang besar, kepada ayah atau neneknya (Azhari, 1984).

Kutipan di atas menunjukkan bahwa perilaku anak di waktu dewasa itu sangat ditentukan oleh pengalaman yang didapatkan melalui pola pendidikan atau pola asuh orang tua di kehidupan rumahnya. Artinya pengaruh yang paling besar sebagai bentuk kehidupan di waktu kanakkanak. Dan waktu kanak-kanak tersebut lebih banyak mendapatkan pengalaman dari rumah. Hal ini sejalan dengan yang dikemukakan Danandjaja bahwa: "anakanak tumbuh menjadi besar dalam lingkungan kerabat itu pula anak menyerap banyak nilai, pengetahuan bahkan lebih banyak dari yang bisa didapatkannya di rumah" (Danandjaja, 1980).

Lebih lanjut Danandjaja mengemukakan (Danandjaja, 1980) melalui penelitiannya didesa Trunyan
Bali. Dari hasil penelitiannya mengemukakan bahwa: pengaruh latar belakang etnografis orang Trunyan, seperti lingkungan hidup, pola menetap, kehidupan sehari-hari, mata pencaharian dan sebagainya terhadap kelakuan dan tingkah laku yang dikembangkan dalam pengasuhan anak. Danandjaja menyimpulkan bahwa konfigurasi kebudayaan atau pola kebudayaan petani Trunyan adalah bersifat introversi, tenang, sabar, bijaksana, dapat menahan diri, bersifat moderat, tidak suka berkelakuan berlebih-lebihan. (Danandjaja, 1980).

Dalam pola pengasuhan anak ini memang sangat beragam, tidak saja pada orangtua memberikan pendidikan kepada anak-anaknya, namun ada juga yang menerapkan pola asuh melalui sistem kekerabatan atau sistem pertalian keluarga. Hal ini dapat dilihat melalui sistem pola asuh yang diterapkan dilingkungan keluarga Jawa. Dimana pola asuh di tradisi Jawa ada juga yang terjadi di etnis Melayu. Sebagaimana dikemukakan oleh Geertz bahwa mengasuh bayi pada dasarnya, mulai dari kain pembedungnya yang lembut sampai pada buaian selendang di pinggang ibunya yang aman serta usaha yang terus menerus menghindari setiap kejutan yang tak nyaman, semuanya diarahkan kepada terbangkitnya sifat pasif. Walaupun pengendalian diri dan kepasifan tersebut sama sekali tidak sama pendekatan yang secara pasif terhadap dunia itu menyebabkan pengekangan diripun luar biasa mudah. Kepasifan itu lebih lanjut diperkukuh di sepanjang masa kanak-kanak itu dengan melalui pengawasan ibu secara ketat yang memadamkan setiap munculnya inisiatif sebelum mulai dilaksanakan (Geertz, 1983).

Pola asuh tradisi Jawa yang dikemukakan di atas, merupakan hasil penelitian. Jika diamati tidak jauh berbeda dengan pola asuh yang diterapkan di etnis Melayu. Dimana etnis Melayu melakukan pola asuh bedungan, etnis Jawa juga melakukan yang dikenal dengan sebutan pembedungan. Dengan demikian pola asuh yang diterapkan orang tua hampir tidak jauh berbeda. Semua anak pasti membutuhkan perhatian dan kasih sayang. Salah satu bagian pola asuh diatas merupakan bentuk perhatian dan kasih sayang orang tua kepada anak-anaknya (Geertz, 1982).

Lebih lanjut Geertz menyatakan dalam adat Jawa bahwa anak sangat disenangi dan diinginkan dalam ucapannya sehari-hari bilamana engkau menjadi tua, anak-anakmulah yang mengurusimu, bahkan bilamana engkau sangat kaya, anak-anakmulah yang mengurusimu takkan tertebus dengan uangmu (Geertz, 1982). Kriteria penting dalam adat jawa adalah pola mengasuh dan melatih bayi antara lain: perawatan bayi pada umumnya, menyusui, makanan tambahan dan menyapih, latihan kesopanan, belajar jalan, belajar kekamar kecil, tidur, perlindungan-perlindungan ritual.

\section{METODE PENELITIAN}

Jenis penelitian ini adalah penelitian kualitatif dengan tujuan mendeskripsikan pola asuh anak etnik Tamiang. Kata "kualitatif" menekankan kepada proses dan makna dengan menganalisis dan memahami pola dan proses sosial masyarakat, yang diakui tidak akan dapat 
diukur dan diuji secara tepat. Data utama penelitian ini adalah data kualitatif yang diperoleh melalui wawancara terhadap informan, baik informan kunci maupun bukan, mulai dari penduduk desa, pemerintahan swasta, maupun Lembaga Swadaya Masyarakat. Pendekatan yang digunakan adalah hubungan lansung di tempat dimana peneliti tinggal bersama masyarakat yang diteliti, atau mendekati suatu masyarakat sebagai suatu sistem sosial yang terpadu. Dengan demikian penelitian ini dilakukan intensif dan berskala kecil, peneliti dapat mengikuti arus kehidupan sosial masyarakat di lokasi penelitian. Dalam pendekatan seperti ini peneliti tidak hanya mengumpulkan informasi tentang hal yang dipercayai, diyakini dan bagaimana mereka bertindak tetapi melihat bagaimana semua itu dikukuhkan dalam kehidupan sehari-hari (Fox, 1978).

Penelitian kualitatif adalah penelitian yang bermaksud untuk memahami fenomena tentang apa yang dialami oleh subjek penelitian misalnya prilaku, persepsi, motivasi, tindakkan, dan lainnya secara holistik, dan dengan cara deskripsi dalam bentuk kata-kata dan bahasa, pada suatu konteks khusus yang alamiah dan dengan memanfaatkan berbagai metode alamiah (Moleong, 2010: 6).

Sebagai penelitian kualitatif, penelitian ini mengetengahkan data secara deskriptif terhadap gejalagejala yang dipelajari dalam konteksnya yang alami (Denzin dan Lincoln, 1994).Selain itu, juga dilakukan analisis untuk mengidentifikasi kaitan sebab akibat dari gejala yang diamati serta mengambil kesimpulan yang menjadi dasar deduktif dan prediktif terhadap berbagai peristiwa di masa mendatang.

Pemilihan pendekatan ini akan melihat masyarakat yang diteliti sebagai suatu sistem sosial yang terpadu dimana deskripsi hasil penelitian secara umum berlaku pada semua warga masyarakat. Deskripsi yang sepenuhnya mengenai penduduk sebagai keseluruhan, sangat mungkin dilakukan dengan menggunakan metode kualitatif (Geetz, 1981). Data kualitatif dari sample yang cukup mewakili keadaan, memudahkan untuk memberlakukan pernyataan umum (Emerson, 1982). Dengan demikian yang dipakai dalam penelitian ini adalah kualitas data yang di peroleh.

Sistem sosial merupakan wujud dari nilai-nilai budaya yang keseluruhannya berpengaruh terhadap pola asuh suatu suku. Nilai-nilai budaya tersebut tentunya merupakan bagian dari kebudayaan yang hidup pada masyarakat Tamiang. Oleh karena itu populasi dalam penelitian ini adalah penggambaran tentang keadaan individu dalam suatu keadaan dan gejala tertentu dari beberapa kebiasaan yang dijalankan oleh kelompok budaya etnik Tamiang. John Dewey dalam (Benedict,1962: 16) mengatakan bahwa riwayat hidup individu terutama sekali ialah penyesuaian diri kepada pola-pola dan ukuran-ukuran, yang turun temurun ada dalam masyarakatnya. Sejak saat ia dilahirkan, adat kebiasaan lingkungan tempat ia dilahirkan menentukan pengalaman dan kelakuannya. Menjelang waktu ia mulai bicara, ia telah merupakan hasil kecil daripada kebudayaannya dan bila sudah dewasa dan sudah bisa ikut serta dalam kegiatan-kegiatan masyarakatnya, maka adat kebiasaan-kebiasaannya, kepercayaan dan laranganlarangan lingkungannya merupakan pula adat kebiasaannya, kepercayaannya dan larangannya. Adapun yang menjadi sampel dalam penelitian ini adalah penduduk desa Sekrak dan Paya udang yang merupakan desa mayoritas etnik Tamiang.

Penelitian ini dilakukan secara kualitatif dengan pendekatan deskriftif interpretatif, yaitu rangkaian penelitian yang berupaya untuk menggambarkan data secermat mungkin mengenai suatu individu, keadaan, gejala, atau kelompok. Penggambaran tentang keadaan individu dalam suatu keadaan dan gejala tertentu dapat terlihat dari beberapa kebiasaan yang dijalankan oleh etnik Aceh Tamiang. Peneliti merupakan partisipan dari kebudayaan Aceh Tamiang, maka peneliti melihat secara langsung bagaimana perubahan-perubahan yang terjadi dalam proses pola asuh anak-anak Aceh Tamiang. Sehingga peneliti dapat mendeskripsikannya dari observasi awal serta mengetahui perubahan-perubahan apa saja yang terlihat dari proses pola asuh anak-anak suku Aceh Tamiang. Dan bagaimana orang tua mereka melakukan proses pola asuh tersebut.

Penelitian ini mengambil lokasi di Kecamatan Seruway, Kecamatan Tamiang Hulu, dan Hilir di Kabupaten Aceh Tamiang. Pemilihan lokasi penelitian berdasarkan pada daerah yang di dominasi oleh etnik Tamiang.

Data dalam penelitian ini diambil dengan beberapa cara, diantaranta observasi, wawancara, studi kepustkaan. Observasi yang digunakan adalah obsevasi partisipasi (participant observation) dan observasi sambil lalu. Melalui observasi ini peneliti dapat melihat tata cara kehidupan sehari-hari. Dengan observasi partisipasi, peneliti dapat mengamati enkulturasi nilai-nilai tradisional pola-pola pengasuhan anak pada etnik Tamiang. Kemudian melihat faktor-faktor yang mempengaruhi pola asuh anak, juga faktor-faktor resistensi yang dapat mempertahankan pola asuh secara tradisional.

Melalui observasi, peneliti akan mengamati penerapan nilai-nilai budaya pada anak-anak remaja dan bagaimana mereka menginterpretasikan dalam kehidupan sehari-hari. Melalui pengamatan ketidak mampuan responden menjelaskan apa yang diperlukan dan adanya gejala yang terjadi dalam masyarakat yang dianggap 
biasa, padahal dari sudut Antropologi hal tersebut sangat penting (Vredenberg, 1983) akan dapat diabadikan. Guna mendukung kevalidan data yang diperoleh melalui observasi ini, peneliti akan menggunakan instrument penelitian berupa kamera foto, untuk mengabadikan peristiwa yang berkenaan kehidupan masyarakat khusus pola pengasuhan.

Wawancara dilaksanakan seperti ditegaskan oleh Lincond dan Guba (Moleong, 2010), antara lain mengkonstruksi mengenai orang, kejadian, organisasi, perasaan, motivasi, tuntutan, kepedulian dan lain-lain kebulatan; mengkonstruksi kebulatan-kebulatan demikian sebagai yang dialami masa lalu; memproyeksikan sebagai yang diharapkan untuk dialami pada masa yang akan datang; memverifikasi, mengubah, dan memperluas informasi yang diperoleh dari orang lain, baik manusia maupun bukan manusia (triangulasi); dan memverifikasi, mengubah dan memperluas konstruksi yang dikembangkan oleh peneliti sebagai pengecekan anggota.

Wawancara terhadap kelompok suku yang diamati secara terstruktur (structurized interviewing) dan tidak terstruktur (unstructurized interviewing). Pada wawancara terstruktur telah dipersiapkan terlebih dahulu bentuk wawancara yang mengarah pada rumusan masalah penelitian berupa pertanyaan-pertanyaan ringkas diseputar tema penelitian. Wawancara ini dilakukan dengan menetapkan terlebih dahulu lokasi Kecamatan Sekrak, dimana daerah ini merupakan daerah yang masih mengentalnya adat istiadat budaya etnik Tamiang. Lokasi yang kedua di daerah kecamatan Paya Udang yaitu daerah pertanian di hulu Tamiang yang masih terlihat budaya etnik Tamiang.

Key informan yang dipilih adalah ketua Majelis Ulama Adat dan juga beberapa tokoh masyarakat yang selalu dilibatkan dalam upacara-upacara adat yang diselenggarakan oleh masyarakat etnik Tamiang di Kabupaten Aceh Tamiang. Sedangkan pada wawancara tidak terstruktur dilakukan secara spontan atau sambil lalu (causal interviewing) sehingga dapat menjajakisemaksimal mungkin fenomena yang terjadi secara tidak terbatas.

Dalam wawancara tidak terstruktur ini peneliti melibatkan beberapa informan terdiri dari warga yang memahami dan mengenal kebudayaannya berdasarkan identitas keterlibatannya dalam suatu kegiatan-kegiatan kebudayaan. Dalam proses wawancara sering dilakukan kepada para kerabat dan lebih sering terlihat langsung dalam proses sosialisasi yang dilakukan terhadap anak.

Selain pengumpulan data melalui pengamatan dan wawancara, pengumpulan data juga dilakukan dengan melalui studi kepustakaan. Secara umum, studi keperpustakaan ini bertujuan untuk pengumpulan data sekunder seperti jumlah penduduk dan monografi lokasi penelitian. Studi kepustakaan ini, akan memanfaatkan badan-badan dokumen yang sedia baik itu laporan resmi instansi terkait, laporan penelitian, catatan harian, bukubuku ilmiah maupun hasil penelitian dari para ahli yang temanya sesuai dengan masa yang diteliti. Dalam memanfaatkan bahan dokumen ini peneliti akan melakukan sesuatu analisa kandungan isi (content analysis).

Dalam penelitian ini, data dihadirkan secara deskriptif tentang gejala-gejala yang dipelajari dalam konteksnya yang dialami (natural setting). Selain itu, juga dilakukan analisis untuk mengidentifikasi kaitan sebab akibat dari gejala yang diamati serta mengambil kesimpulan yang menjadi dasar deduktif dan prediktif terhadap berbagai peristiwa di masa mendatang (Kartono,1986:24). Data kualitatif dianalisis dengan prinsip "analisis data kualitatif" yang terdiri dari tiga alur kegiatan yang terjadi secara bersamaan, yaitu reduksi data, penyajian data, dan penarikan kesimpulan atau verifikasi data (Miles dan Huberman, 1992:15-21). Reduksi data merupakan pemilihan, pemusatan perhatian pada penyederhanaan, pengabstrakan, dan transformasi data"kasar" yang muncul dari catatan-catatan tertulis lapangan; sementara penyajian data merupakan sekumpulan informasi tersusun yang memungkinkan penarikan kesimpulan. Data dianalisis secara deskriptif dengan mengkategorikan jawaban dan ditampilkan dalam tabel analisis. Secara terbatas juga dicakup masalah pendidikan dengan mempelajari sosial budaya, ekonomi, pola asuh anak dan berbagai hal yang mengitarinya.

\section{HASIL DAN PEMBAHASAN}

Pola Asuh Anak Etnik Tamiang Adat Kehamilan dan Kelahiran ${ }^{1}$

\section{- Resam dan Pantang Pemali waktu mengandung(hamil)}

Sebagaimana halnya adat pada etnik lainnya, adat etnis Tamiang juga mengatur hal-hal yang berkaitan dengan kehamilan. Etnis Tamiang sangat memuliakan wanita hamil, karena mengandung calon bayi yang merupakan amanah dan titipan Ilahi serta kelak akan menjadi penerus bagi keluarga.

Setiap etnis memiliki cara dan pola tersendiri dalam sistem pengasuhan anak-anak. Anak-anak dalam keluarga biasanya dididik dengan suatu tata nilai atau pola asuh yang berbeda. Pola asuh itu sendiri merupakan pola interaksi antara anak dengan orangtua yang meliputi pemenuhan kebutuhan pisik (seperti makan, minum dan lain-lain) dan kebutuhan psikologis (seperti rasa aman, kasih sayang dan lain-lain) serta sosialisasi norma-norma

1 Keterangan ini berdasarkan informasi dari Drs. Syarifuddin Ismail yang menjabat Ketua Majelis Pertimbangan Pendidikan Etnik Tamiang 
yang berlaku di masyarakat agar anak dapat hidup selaras dengan lingkungannya. Dengan kata lain, pola asuh juga meliputi pola interaksi orang tua dengan anak yang berkaitan dengan perkembangan pribadi anak yang meliputi cara pemberian kasih sayang dan pendidikan. Orang tua merupakan model bagi perilaku anak-anaknya. Orang tua dapat membentuk perilaku remaja dengan cara memberi contoh melalui perilakunya, mendorong anak untuk berbuat sesuatu yang baik, menunjukkan kepada anaknya bagaimana cara bertindak berkenaan dengan pola asuh orang tua yang terjadi dan salah satunya akan terlihat dalam suatu keluarga.

Keluarga etnis Tamiang menganut sistem kekerabatan bilateral yaitu penghitungan garis keturunan berdasarkan garis keturunan laki-laki ataupun perempuan. Hubungan kekerabatan seperti ini dapat kita lihat didalam dua pola hubungan yaitu hubungan secara vertikal (tegak lurus) dan secara horizontal (garis lurus).

Keluarga etnis Tamiang pada umumnya adalah keluarga yang memiliki kedekatan satu dengan yang lain, baik ayah dengan ibu, orang tua dengan anaknya dan sebaliknya anak dengan orang tua. Hal inilah yang sering dilihat bahwa banyak keluarga etnis Tamiang yang tinggal dalam satu rumah. Terkadang dalam satu bangunan di rumah para keluarga etnis Tamiang baik anggota keluarga yang sudah menikah maupun yang belum, tinggal dalam satu rumah bersama-sama. Dalam masyarakat etnik Tamiang juga terdapat tradisi tradisi anak perempuan Tamiang yang sudah menikah akan tinggal di rumah orang tuanya. Ini mengakibatkan rumah keluarga etnis Tamiang pada umumnya selalu dipenuhi dengan keceriaan dan keriangan anak-anak.

Kedekatan geografis dalam hal tempat tinggal mengakibatkan hubungan kekeluargaan dan pengamatan tentang perkembangan anak-anak semakin diperhatikan oleh para keluarga. Pada proses ini seorang anak dapat melihat dan belajar tentang kepribadian yang ditiru melalui proses belajar dari lingkungan sekitarnya. Proses itu dapat meliputi perasaan, hasrat, nafsu, serta emosi yang diperlukannya sepanjang hidupnya. Kemudian dalam proses penanaman nilai-nilai budaya selanjutnya adalah internalisasi yang menyangkut masalah sistem kepribadian. Sedangkan dalam sistem kepribadian didapat dari proses sosialisasi yang merupakan suatu proses dimana seorang individu belajar pola-pola tindakan dalam hubungan pergaulan dengan segala macam individu disekelilingnya, yang menduduki beraneka macam peranan sosial dalam kehidupan seharihari. Dalam hal ini sosialisasi merupakan proses penempatan individu dalam sistem sosialnya.

Dalam proses ini anak-anak akan terus belajar dengan melihat, mendengar, dan mengimplementasikan nilai-nilai budaya kedalam kehidupan sehari-hari mereka. Pengimplementasian tersebut dapat dilihat dari perilaku anak-anak etnis Tamiang yang terlihat suatu perilaku menghormati orang tuanya dan memperhatikan orang tuanya dan juga sebaliknya.

Proses pewarisan tradisi budaya itu tidak terlepas dari peran keluarga. Keluarga secara harfiah mempunyai pengertian yaitu suatu kelompok yang terdiri atas seorang wanita dan seorang pria dewasa yang keduanya diikat dalam proses perkawinan. Bentuk perkawinan dapat beraneka ragam, mulai dari seorang suami dan seorang istri dengan anak-anak mereka, sampai kelompok besar yang terdiri atas beberapa saudara laki-laki dan perempuan dengan anak-anak saudara perempuan (Haviland, 1993:73).

Keluarga yang selama ini dalam pandangan ilmu Antropologi merupakan suatu unit lembaga sosial inti mempunyai peran yang sangat signifikan dalam proses penanaman nilai-nilai budaya pada setiap kelompok masyarakat. Hakikat dari keberadaan keluarga adalah sebagai upaya untuk bertahan demi kelangsungan hidup kelompok budaya. Hal ini rupanya telah diwarisi dari pendahulu-pendahulu yang dianggap sebagai nenek moyangnya yang mengembangkan dan melangsungkan kehidupannya berdasarkan tata aturan serta norma-norma kebudayaannya. Kelangsungan hidup manusia hanya dimungkinkan oleh adanya kebudayaan yang dimiliki manusia. Tanpa kebudayaannya manusia hanyalah makhluk paling lemah di antara makhluk lainnya. Kenyataan ini dapat dilihat dari kehadiran bayi manusia yang tidak punya kemampuan untuk melangsungkan hidupnya sendirian, berbeda dengan hewan yang dalam genetikanya, ketika lahir langsung memiliki kemampuan dan kapasitas penuh untuk hidup dan melangsungkan hidupnya dengan lengkap. (Ibid)

Proses pewarisan budaya pada umumnya bertujuan untuk menegakkan tradisi-tradisi kemasyarakatan yang kuat, yang menetapkan struktur dan peranan-peranan masyarakat. Proses pewarisan budaya berlangsung sejak masa anak-anak hingga akhir hayat setiap anggota masyarakat, baik dalam bentuk enkulturasi, sosialisasi, dan internalisasi. Proses pewarisan budaya dapat diimplementasikan dengan melibatkan anak-anak pada kegiatan-kegiatan pada upacara-upacara ritual kemasyarakatan. Agen perubahan kebudayan yang sangat penting pada masyarakat adalah keluarga, tokoh masyarakat, dan agama serta lembagalembaga masyarakat lainnya. Keluarga merupakan media dalam mewariskan nilai-nilai budaya yang biasanya mengedepankan kepatuhan dan kehormatan kepada orang tua, kejujuran, keadilan, nilai-nilai spiritual, perihal hak dan kewajiban dan keterampilan-keterampilan yang dimiliki keluarga.

Kelompok etnis Tamiang yang berada di Desa Paya Udang maupun Desa Sekerak melaksanakan adat istiadat yang masih dijalankannya. Berbagai etnis memiliki adat istiadat baik dalam kehidupan bermasyarakat dan khususnya dalam aspek kelahiran. Demikian juga dengan etnis Tamiang memiliki adat istiadat dalam kelahiran. Menurut Muntasir (2003:188) adat kelahiran di etnik Tamiang itu terdiri atas, sewaktu mengandung, bersalin dan sehabis melahirkan.

Walaupun terkadang ada beberapa unsur kebudayaan mereka yang tidak dijalankan sesuai dengan kebiasaannya. Ada beberapa saluran pewarisan nilai-nilai budaya pada setiap masyarakat, baik masyarakat tradisional maupun modern, yaitu yang pertama adalah melalui pengasuhan anak dalam lingkungan keluarga. Saluran kedua adalah sistem pendidikan yang bersifat formal. Saluran yang ketiga adalah kegiatan-kegiatan 
dalam masyarakat yang kurang lebih dapat diikuti oleh umum, seperti kegiatan remaja mesjid, serikat tolong menolong, perwiritan, pengajian, serta banyak lagi aktivitas-aktivitas lain yang berhubungan dengan kontak sosial dan kehadiran masyarakat dalam aktivitas tersebut. Saluran-saluran tersebut memberikan pengaruh dalam merubah cara berfikir seseorang. Sehingga dalam konteks pola pengasuhan anak juga mempengaruhi proses penanaman nilai-nilai budaya dalam keluarga.

Adat istiadat yang juga selalu diajarkan orang tua kepada anak-anak mereka adalah adat tentang masa kehamilan ibu sampai masa kelahiran bayi. Dalam Selayang Pandang Daerah Kabupaten Aceh Timur, 1972:68, suatu kebiasaan bahkan adalah juga merupakan adat Resam di Tamiang apabila seorang ibu mempunyai anak perempuan (istilah Tamiang: anak puan) dan anak tersebut telah pula selesai ditempatkan (telah bersuami) maka perubahan pada tubuhnya semenjak ia bersuami selalu dalam pemilikan/pemantauan ibunya. Sebaliknya, sianakpun selalu menyampaikan suatu yang terasa pada dirinya kepada ibunya sendiri terlebih dahulu.

Setelah ibunya yakin menurut tanda-tanda yang dilihat pada anaknya perempuannya, si ibu memberitahukan kepada besannya yang perempuan bahwa sianak/menantu mereka telah mengandung. Semenjak itu sianak yang mengandung tadi tidak boleh teledor sedikitpun dari penjagaan ibunya dan ibu mertuanya harus pula selalu datang menjengunk.

Famili dari kedua belah pihak maupun orang tua kampung selalu memberikan nasihat-nasihat dan memberitahukan hal-hal yang harus dihindarkan supaya jangan terkena atau terlanggar pantang atau pemali menurut kepercayaan etnis Tamiang atau yang telah dijalankan para leluhur mereka. Kesemua pantangan itu dikhawatirkan akan membawa pengaruh buruk baik terhadap janin yang sedang dikandung maupun terhadap orang yang sedang mengandung.

Selain pantangan juga sangat ditekankan supaya perempuan yang sedang mengandung melaksanakan perbuatan-perbuatan yang baik, yang kesemuannya itu diharapkan kelak nantinya sianak akan menjadi anak yang shaleh, baik hati dan berbakti pada orang tua. (Muntasir, 2003: 65)

Adapun beberapa hal yang harus dilakukan oleh perempuan yang mengandung/hamil dalam kebiasaan etnis Tamiang diantaranya:

- Memperbanyak sedekah dan ikhlas dengan harapan dimudahkan proses persalinan, dan sianak diharapkan menjadi anak yang dermawan.

- Senantiasa membawa besi putih yang sebelumnya telah dibacakan tasbih dan tahlil, dipercaya akan mengusir gangguan-gangguan makhluk halus, karena wanita hamil rentan sekali akan gangguan semacam itu.

- Bangun tidur lansung beraktifitas, tidak boleh bermalas-malasan apalagi sampai tidur lagi, hal ini mengajarkan calon bayi senantiasa giat dalam berusaha.

- Memperbanyak gerak, hal ini dipercaya juga akan memudahkan proses persalinan.
- Memperbanyak makan sayur dan buah, diharapkan calon bayi sehat dan bergizi.

- Disarankan minum air kelapa, dipercaya agar calon bayi bersih

- Disarankan makan pulut kuning, dipercaya agar calon bayi cantik atau tampan

- Memperbanyak membaca Al-quran, terutama surat Maryam(jika ingin anak perempuan dan sholeh seperti Siti Maryam), atau surat Yusuf(jika ingin anak laki-laki, setampan dan shaleh seperti Nabi Yusuf)

- Memperbanyak menhadiri pengajian, diyakini calon bayi mendengar sehingga ia akan terbiasa mengaji dan ke Mesjid.

- Jika terjadi gempa bumi disarankan naik keatas dapur. Sebaliknya, ada beberapa hal yang tidak boleh dilakukan oleh wanita hamil dalam pandangan kebiasaan etnis Tamiang diantaranya:

- Dilarang memotong rambut

- Dilarang melintasi bagian belakang tubuh wanita hamil, karena dipercaya akan menyebabkan sakit pinggang.

- Dilarang makan beralaskan daun

- Dilarang makan dan minum beralaskan piring dan gelas yang cacat, seperti retak, atau sumbing, dipercaya dapat menyebabkan calon bayi cacat.

- Dilarang menyakiti ataupun membunuh binatang, karena diyakini akan menyebabkan calon bayi cacat atau kekurangan bagian tubuh.

- Dilarang memancing, karena dipercaya dapat menyebabkan calon bayi terluka ataupun cacat.

- Dilarang keluar rumah pada waktu mahgrib, karena dipercaya pada waktu tersebut makhluk halus berkeliaran.

- Dilarang mandi pada waktu maghrib karena dipercaya ada jin yang suka mengganggu orang yang sedang mandi pada waktu maghrib.

- Dilarang duduk didepan pintu dipercaya barakibat pada lamanya calon bayi keluar.

- Dilarang duduk diatas batu

- Dilarang duduk dilantai tanpa alas, ditakutkan ketika melahirkan uri sibayi akan lengket.

- Dilarang melilitkan selendang ataupun handuk pada leher, dipercaya dapat mengakibatkan calon bayi terlilit oleh tali pusatnya.

- Dilarang keluar rumah ketika gerhana dan melihat gerhana dikhawatirkan si calon bayi lahir dalam keadaan belang wajahnya.

\section{- Menempah Bidan}

Pada dasarnya, peran bidan sangat mempengaruhi kehadiran seorang bayi. Dahulu bidan beranak lebih dikenal dengan dukun beranak. Menurut adat di Tamiang apabila si pengantin diyakini telah mengandung lebih kurang enam atau tujuh bulan maka ibu dan ibu mertua mufakat untuk meminta pertolongan bidan guna membantu proses kelahiran. Jaman dahulu ketika masih ada hukum dan adat mutlak harus dijalankan dan dipatuhi, meminta bantuan bidan mempunyai cara-cara tertentu yang telah diatur sepanjang adat resam yaitu 
"Tempah Bidan" karena bidan dapat dibatalkan oleh kepala adat menurut tingkatnya masing-masing. (Selayang Pandang Daerah Kabupaten Aceh Timur, 1972:68). Pada masa sekarang, tradisi menempah bidan masih dipertahankan oleh masyarakat keluarga Tamiang, akan tetapi tidak menggunakan upacara adat lagi.

Ibu si pengantin yang sedang mengandung bersama-sama dengan mertuanya terlebih dahulu harus mempersiapkan:
a. Sirih setepak
b. Pakaian sesalin
c. Uang seringgit

Ketiga benda tersebut dibawa lalu di serahkan kepada bidan yang bersangkutan setelah bidan menerima dan menyanggupi tempahan itu, ianya membuatkan "tangkal" benang pancawarna yaitu benang yang terdiri dari lima warna yang telah dirajah ditambah dengan sepotong kemenyan dan putik limau mungkur tiga buah untuk dipakai oleh pengantin yang sedang mengandung tersebut.

Pada jaman dahulu apabila bidan yang telah ditempah, kemudian pada saat diperlukan ia mangkir, maka perbuatannya itu telah melanggar resam adat dan ia akan dipersalahkan oleh kepala Adat (Datu/Raja) menurut adat empat kaum. (Selayang Pandang Daerah Kabupaten Aceh Timur, 1972:69)

Upacara tempah bidan dilakukan sebagai penghormatan mertua terhadap menantunya yang sedang hamil untuk menghadapi kelahiran anak pertamanya. Karena ia belum pernah merasakan susah payahnya melahirkan, maka ia dihibur dengan diberi makanan yang enak-enak. Ibu hamil dalam adat Tamiang mendapat perlakuan yang manja dari sanak keluarga. Pada upacara ini, yang datang menjenguk dari pihak ibu laki-laki adalah kaum kerabat dan tetangga yang perempuan saja sedangkan yang laki-laki tidak. Kunjungan ini biasanya dikabarkan terlebih dahulu kepada pihak keluarga perempuan sehingga mereka melakukan persiapan untuk menyambut kedatangan kaum keluarga dan beberapa orang sesepuh kampung. Setelah selesai makan, dilakukanlah pesejuk (tepung tawar) oleh keluarga dari pihak laki-laki. Setelah upacara pesejuk selesai, si ibu hamil bersalaman dengan semua rombongan untuk memohon maaf dan doa restu sambil bersujud pada mertua dan ibu kandungnya.

Upacara dilanjutkan, dimana mertua menyerahkan menantunya kepada mak bidan(dukun beranak) dengan mengatakan "ne idup mati anak ambe, entah siang entah ke malam hari, ambe serah ke kak mak bidan untuk ngurusnya sampe selesai”, lalu mak bidan pun menerimanya dengan ucapan "kite ne kan berusahe umor kak Tuhan”. (Muntasir,2003:186). Setelah selesai serah terima diberikanlah bahan-bahan tersebut kepada mak bidan. Sejak saat itu, biasanya mak bidan secara berkala datang mengontrol, biasanya juga sekaligus sebagai tukang urut(kusuk) sampai selesai melahirkan dan turun tanah.

\section{- Menyambut bayi / melahirkan}

Ketika melahirkan anak pertama, semua ibu muda memiliki perasaan was-was. Di lingkungan etnis Tamiang biasanya ketika akan melahirkan seluruh keluarga terdekat berkumpul. Turut serta juga para tetangga bersama-sama selain membantu pekerjaan rumah, juga menghibur yang akan melahirkan agar tidak takut dan was-was akan apa yang akan dihadapinya.

\section{a. Menyambut bayi}

Ketika terdapat tanda-tanda bahwa bayi akan lahir, ibu segera menyuruh menantunya menjemput bidan yang telah ditempah, selanjutnya memberitahukan kepada sanak saudara yang terdekat bahwa istrinya hendak melahirkan.

Sanak saudara terdekat dan jiran selingkar yang telah diberitahukan segera datang menolong untuk mempersiapkan segala sesuatunya. Setelah bidan datang, kemudian disiapkan tempat bagi perempuan yang akan melahirkan, yaitu di ruang (serambi) belakang dari rumah induk. Sewaktu bayi tersebut lahir, ia segera disambut bidan, dikeratkan pusatnya dengan sembilu buluh. Sekarang dengan silet yang tajam, lalu diobati dengan arang, kunyit dan lainnya. Sebelum tali pusat dikerat, terlebih dahulu pangkal pusatnya diikat, laki-laki tujuh ikatan sedangkan perempuan lima ikatan. Kemudian barulah bayi tersebut dibersihkan (dimandikan) dan dilangiri (bedak limau)

Setelah dimandikan, di atas kepala bayi dipecahkan kelapa dengan dilapiskan kain panjang, hal ini dilakukan agar bayi tersebut tidak terkejut oleh petir (lintar). Selanjutnya sibayi disemburi dan digunggungi (dibedung). Setelah itu bayi diserahkan kepada ayahnya untuk diazankan bila laki-laki dan diqamatkan bila perempuan. Setelah selesai semua maka bayi diserahkan kepada salah seorang familinya yang terkemuka.

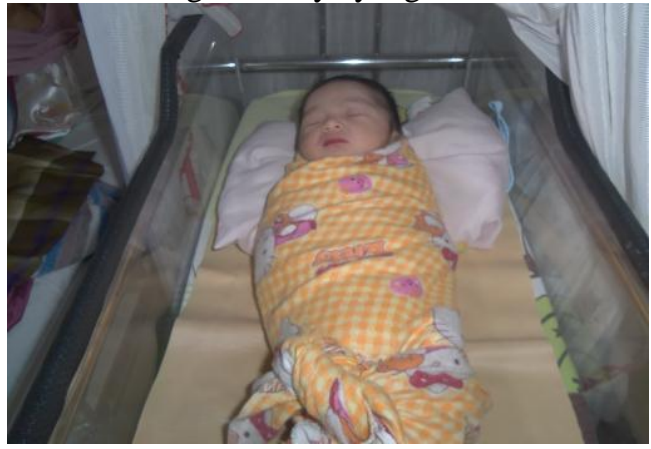

Gambar 1: Bayi yang baru lahir dibedung (salah satu adat Tamiang)

\section{b. Cukur Rambut}

Setelah anak berumur satu minggu atau menurut kondisi rambut yang dibawa oleh bayi sejak lahir, bila rambut bayi tebal maka akan dilakukan cukur rambut. Terkadang juga adat cukur rambut ini dilakukan bersamaan dengan turun tanah, dimana bayi sudah berumur 44 hari. Namun kebiasaan masyarakat Tamiang selalu mengambil hari-hari ganjil seperti usia bayi 41 hari, 43, atau 45 hari. Adapun tujuan mencukur rambut 
ini yaitu untuk membuang rambut yang kotor. Pada saat cukur rambut ini juga diadakan kenduri menurut kemampuan orang tua.

Pada saat kenduri acara cukur rambut, ibu dari pihak laki-laki datang bersama sanak keluarga dengan membawa berbagai alat peralatan untuk keperluan mencukur. Adapun tata cara mencukur rambut tersebut yaitu, bidan mengusap air pada rambut bayi dengan memakai sabun. Kemudian rambut yang sudah dicukur dimasukkan ke dalam kelapa muda yang telah dilubangi lalu ditutup dan kemudian ditanam dalam tanah. Hal ini dilakukan sebagai salah satu syarat agar rambut bayi cepat tumbuh dan subur. Sebelum pencukuran dimulai, terlebih dahulu dilakukan tepung tawar.

\section{c. Nyejapi bayi ${ }^{2}$}

Setelah adat mencukur rambut bayi proses adat selanjutnya adalah nyejapi bayi. Maksud dari nyejapi bayi yaitu bayi di njejapi dengan manisan lebah dimana diharapkan sibayi dapat merasakan yang manis-manis dan melakukan juga mengucapkan yang baik-baik. Caranya ialah dengan terlebih dahulu memasukkan Sebentuk cicin suasa kedalam manisan lebah lalu cicin suasa tadi dijejapkan kedalam mulut sibayi dengan terlebih dahulu mengucapkan "Bismilahirrahmannirrahim", dan kemudian dilafazkan kalimat "Manis-manis ludahmu panjang umurmu, murah rezeki taat dan beriman dalam hidupmu serta terpandang dalam kaum".

Setelah selesai nyejapi, bayi dibaringkan di atas daung (dulang) yang telah dihiasi seperlunya. Cincin suasa yang dipergunakan untuk menjejapi tadi dipulangkan (diserahkan) sementara kepada bidan yang nantinya setelah habis berdapur empat puluh empat hari akan ditebus cincinnya dinamakan "lapik ngerat tali pusat". Setelah bayi dibersihkan, temannya bayi (adinya atau urinya) menurut kebiasaan adat Tamiang oleh bidan di tanamkan di halaman rumah. Menurut bidan yang berpengalaman ada tiga jenis alir tali pusat pada tiap-tiap bayi yang baru dilahirkan yaitu:

1. Yang berselubung usus

2. Yang berputar linan

3. Yang berbenang serat (Muntasir, 2003: 143)

Yang berselubung usus, ditanamkan di halaman dan yang berbenang serat di kiri naik (tangga naik) dan yang berputar linan ditanamkan di tengah halaman. Bila anak laki-laki dapat ditandai pada bekas penanaman uri/temuni dibuatkan empat patok sedangkan pada anak perempuan tiga patok. Jika pada anak diwaktu dilahirkan berselendang usus maka anak tersebut ditepung tawari guna sempurna. Kadangkala ada pula yang dilahirkan

${ }^{2}$ Keterangan ini berasal dari ibu Laila seorang bidan kampung warga Etnik Tamiang. Ia selalu dipanggil oleh warga desa Sekerak dan sekitarnya ketika ada ibu yang akan melahirkan. bersarung. Suatu kepercayaan pula ditengah-tengah masyarakat Tamiang bahwa sarung tersebut dapat dijadikan obat kuat dan kebal bagi anak tersebut. Adapun dalong (dulang) tempat pembaringan bayi tadi, haruslah dialasi dengan "sengora" ditaburi dengan beras di atasnya dikembangkan (lipatan kain panjang) dan kain sarung sebanyak tujuh lapis dan terakhir dialasi dengan kain sutera halus, barulah bayi tadi dibaringkan diatasnya.

Setelah pusat bayi tanggal atau putus biasanya lima sampai tujuh hari, maka beras lapik daleng dimasak dan dikendurikan. Selama sebelum tanggal pusat sibayi, bidan setiap hari harus memandikan bayi dan memberikan obat-obatan seperlunya.

\section{d. Hakikah $^{3}$}

Upacara hakikah ini merupakan adat istiadat Tamiang yang bersesuaiang dengan agama. Bagi mereka yang mampu harus melaksanakan dengan ketentuan untuk anak laki-laki disembelih dua ekor kambing jantan dan untuk anak perempuan satu ekor saja. Adapun syaratsyaratnya adalah bahwa kambing yang akan disembelih harus sudah cukup umur yaitu 1 tahun dan tidak ada cacatnya.

Nenek dari pihak perempuan menyediakan alatalat seperti cermin, bedak, payung, sisir, dan kain putih. Sebelum disembelih kambing tersebut ditepungtawari terlebih dahulu dan dihiasi dengan bedak, sisir, dan kemudian ditunjukkan kea rah cermin. Adapun pekerjaan ini dilakukan oleh imam yang sebelumnya telah dilakukan penyerahan oleh ayah si bayi kepada imam tersebut. Penyembelihan tersebut dilakuakn dengan cara memayungi kambing yang sudah dibaringkan, kemudian kain putih dibentangkan di atasnya dengan dipegang keempat sudutnya oleh empat orang yang akan mengerjakan hasil penyembelihan itu. Keempat sudut kain putih itu disimpulkan dengan uang yang jumlahnya berdasarkan kemampuan. Adapun uang tersebut kemudian akan menjadi hak milik orang yang memegang sudut kain tersebut sebagai upah untuk mengerjakan kambing yang telah disembelih. Adapun bahan-bahan seperti sisir, cermin, kain putih dan payung kemudian diserahkan kepada imam untuk menjadi hak miliknya. Kemudian kambing yang sudah disembelih tadi dimakan bersama-sama oleh keluarga dan para tetangga yang diundang.

\section{e. Masa bedapur ${ }^{4}$}

Menurut adat kebiasaan di Tamiang, tiap orang yang bersalin (melahirkan) si ibu diharuskan bedapur atau berdiang selama 44 hari dan selama itu perawatanya berada didalam tangan bidan. Selama masa bedapur itu siibu tidak dibenarkan melanggar pantang-pemali

\footnotetext{
${ }^{3}$ Wawancara dengan Bapak Samad. Bapak ini adalah seorang imam kampung yang dipandang alim dan memiliki banyak pemahaman agama. Beliau tinggal di desa Sekrak Kanan.

${ }^{4}$ Wawancara dengan Muntasir, Penulis buku Tamiang dalam Lintasan Sejarah
} 
berdapur misalnya makanan yang bisa menyebabkan gatal serta bekerja berat.

\section{f. Mupus}

Setelah dua atau tiga hari setelah bersalin sudah pula merupakan resam adat, bahwa si ibu yang bersalin mendapat kunjungan dari para wanita-wanita keluarga dekat dan jauh, terutama terlebih dahulu adalah kunjungan ibu mertuanya yang menbawakan pulut kuning dalam balai atau daleng dan seperangkat tepung tawar.

Seperangkat perlengkapan yang dibawa untuk menepung tawari simenantu yang bersalin dan si bayi (cucunya), keduanya disuntingi serta disulangi dengan pulut kuning, juga diberi hadiah sehelai kain panjang. Kunjungan membawa pulut kuning atau nasi lada dan hal lainnya semacam itu silih berganti dilakukan oleh kedua belah pihak sampai habis masa bedapur yaitu selama 44 hari.

\section{Menuruntanahkan anak (Turun dapogh)}

\section{a. Turun tanah}

Setelah masa bedapur habis maka diadakan upacara kenduri cukur bayi/turun tanah dan memberi nama. Kebiasaan resam adat di Tamiang upacara turun tanah diadakan kenduri yang disertai dengan marhaban sambil mengayun bayi tersebut. Kadangkala upacara ini sekaligus dengan penyembelihan hakikah (bila belum dilaksanakan) maupun secara tersendiri. Pertama sekali dihiasi bayi dan dibaringkan dalam ayunan yang telah dihiasi serba indah dan digantungkan di tengah-tengah ruangan yang dikelilingi oleh peranggotaan Marhaban. Sewaktu marhaban dimulai bayi tersebut mulai pula diayun dan setelah anggota marhaban berdiri, bayi diangkat dari ayunan oleh salah seorang keluarganya yang ditunjuk oleh orang tua si bayi, lalu diletakkan dikain yang beralaskan tikar ijok berlapis dan didampingi oleh seorang pengapik yang membawa dalong atau talam yang berisikan:

1. pulut kuning

2. perangkatan tepung tawar

3. kelapa muda yang ditebuk(diukir) dan kelapa tumbuh

4. pisau lipat

5. gunting

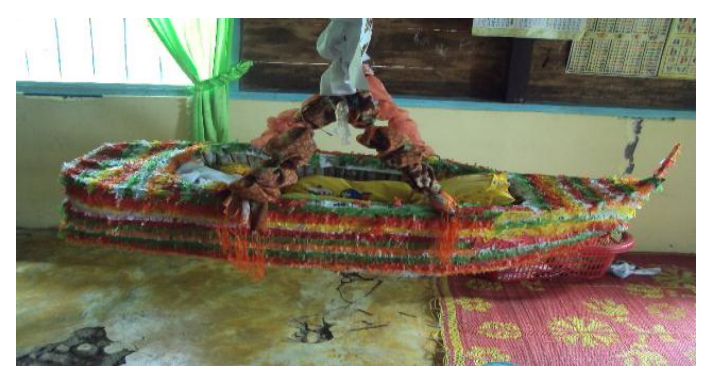

Gambar 2: Acara penabalan nama bayi diayunkan dan dimarhabankan pada acara kenduri
Selanjutnya bayi dibawa berkeliling menemui satu persatu para anggota marhaban yang yang dimulai dari muka tuan guru marhaban, dan sibayi sitepung tawari oleh tuan guru. Selanjutnya mengunting rambut sibayi sedikit dan guntingan rambut tersebut dimasukkan kedalam kelapa bertebok tadi yang telah tersedia didalam talam.Upacara penepung tawaran dan mengunting rambut bayi dilakukan berkeliling dan bergantian oleh anggota marhaban.

Terakhir sibayi oleh yang ibunya diserahkan kepada bidan untuk menyelesaikan pencukurannya. Sementara bidan menyelesaikan penjukurannya, dihalaman rumah telah disediakan "tempat bersiram" yang dihiasi dan dibentuk dengan segala perlengkapannya, dalong berisi tepung tawar, bedak langir dan air mandi yang kesemuanya tempatnya dihiasi menurut hukum peradatan dan sesuai menurut tingkatannya.

Rambut sibayi yang telah dicukur tadi ditimbangkan sama berat dengan uang emas ataupun uang perak dan kemudian uang tersebut diserahkan ataupun disedekahkan kepada orang yang pantas menerimanaya(fakir miskin).

Menuju tempat bersiram atau mandi telah siap sedia anggota pelintau untuk mengadakan silat penyambutan/penghormatan(rebas tebang). Sibayi yang telah selesai dicukur oleh sibidan, segera digendong oleh orang yang telah ditentukan dan si penggendongpun harus dihiasi seperlunya.

Jika anak yang diturun tanahkan itu laki-laki maka yang mengendongnya adalah laki-laki pula demikian pula sebaliknya. Setelah itu sibayi digendong berjalan dibelakang bidan dan orang tua sibayi menyusul dibe;lakangnya, seterusnya diiringkan oleh keluarga dan orang banyak berjalan menuju pintu depan. Di pintu depan telah disiapkan payung yang berkembang, dan sibayi dipayungi menuju tempat bersiram, dalam suasana silat rebas tebang dan bunyi-bunyian (gong-gendangbiola). Sewaktu turun tangga sibidan menyiramkan abu kekiri dan kekanan.

Ditempat bersiram sibayi ditepung tawari beserta dengan orang tuanya. Selesai tepung tawar bayi barulah dimandikan yang didahului dengan membelah kelapa yang dialasi pada siraman pertama dengan nasi kulah dan disambut oleh sipengendong bayi. Setelah selesai bersiram anak tersebut digendong kembali lalu dibawa naik kerumah. Didepan pintu anak tersebut telah dinantikan oleh keluarganya dengan beras - padi ditaburkan menyambut anak naik dengan mengucapkan "serampak serimbun, berampak berimbun, betuah berbahagia, bebuku bermata, becabang beperdu, baik pintar makbul doa jauh bala hidup subur panjang umur". Selamat-selamat karena semangat silakan naik waktu memasuki rumah sipengendong mengucapkan salam (assalammu'alaikum) dengan iringan kata "kami pulang mandi”.

Bayi terus dibawa keruang yang telah dihiasi, lalu di riba oleh keluarganya, dan imam mensaduakan nama untuk anak tersebut yang telah dipilihakan oleh orang tuanya. 
Waktu untuk menurunkan mandi bayi pada adat Tamiang biasanya pada waktu matahari sedang naik dan rambut yang telah dicukur tadi bila anak perempuan dimasukkan dalam kulit pisang dan ditanamkan kembali, bila pisang itu berbuah buahnya disedekahkan. Bila anak laki-laki tanamkan sama-sama kelapa yang tumbuh. Setelah para hadirin dalam upacara kenduri selesai makan semuanya maka selesai sudah acara tersebut.

\section{b.Membasuh Tangan Bidan}

Selesainya kenduri turun tanah maka telah selesailah tanggung jawab bidan terhadap ibu yang sedang bersalin dan sibayi. Sesudah para tamu pulang, maka bidan membuang abudapur tempat berdiang berikut sekalian alat-alat lainnya dipindahkan yang berarti masa berdapur telah selesai dan berakhir. Maka siibun yang bersalin tadi dimandikan dan dilangiri pula, demikian pula seluruh rumah ditepung tawari.

Akhirnya sibidan, ibu siperempuan dan ibu mertua menepung tawari perempuan yang melahirkan tadi, dibasuhkan tangan dengan air limau purut, seterusnya pada bidan dimintakan izin maaf atas jeri payah dan bantuannya diserahkan pula:

a. pakaian sesalin

b. uang sedikit-dikitnya dua ringgit(sekarang 200 ribu)

c. uang lepik tali pusat penebus cincin suatu alat penyecap yang masih dipegangnya sejumlah setali(sekarang lebih kurang 100 ribu)

d. beras benar saro (sekumpik)

e. padi segantang

f. pulut kuning dan pangang ayam serta seekor ayam hidup

Demikianlah selesailah kewajiban kedua belah pihak sepanjang pengertian nempah dan basuh tangan bidan. $^{5}$

\section{c. Mengkhitankan anak}

Salah satu adat Tamiang yang juga bersesuaian dengan agama yaitu mengkhitankan anak. Para orang tua pada umunya akan mengkhitankan anak laki-laki mereka jika sudah layak umurnya.

Sebelum anak dikhitan, maka anak diharuskan membaca kalimat syahadat terlebih dahulu. Setelah dikhitan anak diberi minum air putih bekas rendaman ujung rambut ibunya. Hal ini dilakukan dengan maksud sebagai penawar bisa. Selanjutnya, orang mengngkat talam peminum yang berisikan air putih beserta irisanirisan limau purut. Air dan limau purut ini kemudian diberikan kepada ayah si anak untuk membersihkan tangan yang melakukan khitan pada anak dan kemudian ditepungtawari. Kemudian si ayah meminta izin kepada yang mengkhitankan si anak seraya menyerhakan beberapa hal berikut ini;

a. Sejumlah uang sesuai dengan kemampuan.

b. Kain putih sekabung

c. Ayam seekor

${ }^{5}$ Berdasarkan wawancara dengan salah satu penduduk desa Paya Udang yaitu Pak Mahmud. Beliau termasuk salah satu orang terkemukan dan banyak mengetahui adat istiadat etnik Tamiang d. Beras benar sesupik

e. Padi segantang

f. Kelapa dua buah.

Dalam adat Tamiang, jika terjadi suatu hal yang tidak diinginkan setelah anak dikhitan yang menyebabkan bahaya bagi si anak seperti kematian misalnya, maka orang yang mengkhitankan tersebut dikenai salah adat dan wajib membayar salah adat kepada orang tua si anak berupa;

a. Sirih lengkap secorong

b. Pulut kuning dan ayam panggang sedulang

c. Kain putih sekabung

d. Tebu dua puluh tujuh batang

e. Pisang raja secukupnya

f. Kambing seekor

g. Sejumlah uang

Orang yang mengkhitankan itu wajib menyerahkan salah satu dari anaknya sebagai ganti dari anak yang meninggal sebagai tali yang mempersatukan dua keluarga. Hal ini disaksikan oleh kepala adat dan imam kampung. Akan tetapi, seiring perkembangan zaman, adat ini sudah tidak dilaksanakan lagi. Adapun proses pengkhitanan anak sekarang sudah dilakukan oleh mantri atau dokter yang ahli. Demikian juga dengan syarat-syarat di atas juga sudah tidak dilaksanakan lagi. Hal ini karena menurut wawancara dengan bapak Drs. Syarifuddin ${ }^{6}$ masyarakat sekarang termasuk orang-orang Tamiang lebih cenderung praktis dalam berbagai hal termasuk mengkhitankan anak. Adapun kebiasaan yang berlangsung saat ini yaitu orang tua cukup membayar uang kepada mantri atau dokter yang mengkhitankan anak tanpa menepungtawari mantri atau dokter tersebut.

\section{Hubungan anak dan orang tua}

Dalam hal pembagian kerja, berdasarkan observasi dan wawancara dengan ibu Aisyah ${ }^{7}$, antara anak laki-laki dengan perempuan, beliau menyatakan bahwa ada perbedaan. Kepada anak laki-lakinya sibapak berkewajiban mendidik anak bekerja untuk pribadi seperti berbelang, berhuma, membuat kebun, dan segala keperluan rumah tangga. Sedangkan untuk anak perempuan disediakan alat dan bahan untuk kerja tangan seperti bahan anyaman, kerawang, dan jahit menjahit juga pekerjaan didapur. Kalau ada kemungkinan atau kampung terdekat mengerjakan (pesta kawin atau seumpama), pemuda dan pemudinya disuruh menyamai kerja itu sampai selesai, dengan pesan agar supaya memperhatikan pelaksanaan adat resam kanun yang dilaksanakan dalam upacara dimaksud, untuk diresapi dan diingat sebagai ilmu pengetahuan.

Apabila kedapatan tingkah laku yang mungkin membawa akibat buruk, segera siibu menyampaikan kepada sibapak maka sibapaklah yang bertindak secara bijaksana. Ibu-ibu pada etnis Tamiang sangat lemah lembut dalam mendidik anak-anaknya, segala persoalan selalu mereka limpahkan kebapak atau bekerja sama

${ }^{6}$ Beliau adalah Ketua Majelis Pendidikan Tamiang

${ }^{7}$ Salah satu ibu rumah tangga yang bekerja sebagai guru. Ibu Aisyah tinggal di desa Sekerak 
dengan bapak/suami dalam memecahkan masalahmasakah anak-anaknya. Siibu senantiasa mengamatamati segala tingkah laku anaknya serta memberi nasehat dan petuah.

Hubungan antara saudara laki-laki dan perempuan sangat harmonis dalam etnis Tamiang. Antar laki-laki dan perempuan saling menghargai dan menghormati. Dimana siadik menghormati siabang, dan siabang menyayangi adiknya, begitu juga terhadap saudara perempuan mereka sangat melindungi sesuai dengan perintah agama. Hal ini diajarkan kepada anak-anak etnik Tamiang sejak mereka berusia 2 atau 3 tahun. Sebagaimana hasil wawancara dengan bapak Syarifuddin Ismail ${ }^{8}$ yang menyatakan sebagai berikut: "Anak-anak Tamiang sejak umur umur 2 atau 3 tahunan sudah dikenalkan dan diajarkan kepada mereka tentang adat istiadat Tamiang, tentang kesopanan dan akhlak yang baik yang sejalan dengan agama”.

Dalam kelompok etnis Tamiang dikenal beberapa panggilan dalam hubungan pertalian darah dalam keluarga. Istilah-istilah tersebut diklasifikasikan berdasarkan tingkatan atau struktur anggota keluarga. Dalam garis hubungan masyarakat Tamiang mengadopsi system bilateral, yang artinya menghitung garis keturunan berdasarkan ayah dan ibu.

Hubungan anak dalam keluarga sangat jelas dilihat dari struktur yang ada di atas. Posisi anak dalam keluarga ditunjukkan melalui istilah-istilah pemanggilan yang terdapat pada tradisi Tamiang. Sejak kecil anak etnis Tamiang sangat dekat dengan keluarga mereka. anak-anak tersebut juga diberikan tugas dan tanggung jawab berdasarkan jenis kelaminnya. Pemberian tanggung jawab kepada anak-anak yaitu dengan membiasakan atau melibatkan mereka dalam berbagai aktivitas dalam rumah tangga.

\begin{tabular}{|r||c||c|}
\hline $\begin{array}{c}\text { Urutan } \\
\text { Kelahiran }\end{array}$ & $\begin{array}{c}\text { Istilah } \\
\text { Penyebutan }\end{array}$ & $\begin{array}{c}\text { Istilah } \\
\text { Sapaan }\end{array}$ \\
\hline \hline Anak ke 1 & Ulong & Yong \\
\hline \hline Anak ke 2 & Ngah & Ngah \\
\hline \hline Anak ke 3 & Alang & Ayang \\
\hline \hline Anak ke 4 & Uteh & Uteh \\
\hline \hline Anak ke 5 & Andak & Ndak \\
\hline \hline Amak ke 6 & Uda & Uda \\
\hline \hline Anak ke 7 & Itam & Tam \\
\hline \hline Anak ke 8 & Acit & Cit \\
\hline Anak ke 9 & Uncu & Ncu \\
\hline
\end{tabular}

Tabel 1. Istilah penyebutan atau sapaan dalam keluarga etnis Tamiang

Pembagian pekerjaan ini berkaitan dengan cara pengasuhan orang tua. Karena dengan cara ini orang tua memperkenalkan tanggung jawab, sehingga menjadi bekal keterampiannya di masa mendatang. Hal ini juga terkadang dihubungkan dengan perilaku anak. Melalui pembagian tugas ini juga anak-anak menunjukkan keikut sertaannya dalam aktiviatas-aktivitas keluarga dan

${ }^{8}$ Ketua Majelis Pertimbangan Pendidikan membantu meringankan beban orang tua mereka. Hubungan antara orang tua dengan anaknya mencerminkan suatu keharmonisan, dan ini dapat mempengaruhi perilaku anak dari mulai kecil hingga anak dewasa. Sebuah keluarga yang memiliki beberapa orang anak, biasanya memiliki cara-cara tertentu sehingga setiap anak tidak ada yang merasa dibedakan dengan saudaranya sendiri. Selain itu setiap anak sejak masih kecil sudah diberikan tanggung jawab mengerjakan pekerjaan rumah seperti mencuci piring, menyapu halaman, menyapu rumah, membereskan tempat tidur, dan lain-lain.

Pembagian pekerjaan rumah antara anak laki-laki dan perempuan hanya dibedakan berdasarkan konsep lokal saja, artinya disini bahwa anak perempuan biasanya mendominasi pekerjaan dalam ruang lingkup rumah tangga seperti menyapu, mencuci piring, memasak, dan lain-lain. Sedangkan anak laki-laki biasanya tidak terlalu dibebankan pada pekerjaan-pekerjaan rumah tangga. Berbeda pada kasus pembagian kerja antara anak perempuan yang kecil dan adik perempuannya. Pembagian pekerjaan berdasarkan umur ini diklasifikasikan berdasarkan tingkat kerumitan pekerjaan yang akan dijalani. Misalnya seperti anak-anak ibu Aton, menurut penuturan ibu tersebut biasanya pekerjaan rumah dibagi berdasarkan umur anak, biasanya anak yang paling besar mendapatkan pekerjaan yang lebih banyak dan lebih berat, sedangkan anak yang lebih muda (adik) mendapatkan pekerjaan yang lebih sedikit dan lebih ringan. Jenis pekerjaan rumah si kakak seperti mencuci piring, menyapu rumah dan juga menjaga adiknya. Sedangkan si adik biasanya mendapat pekerjaan membereskan tempat tidurnya, menyiram bunga dan sering disuruh ibunya ke warung untuk membeli sesuatu.

Pembagian kerja berdasarkan jenis kelamin dapat dilihat dari pekerjaan yang dilakukan antara anak lakilaki dan anak perempuan. Biasanya anak laki-laki mendapatkan pekerjaan yang lebih berat dari pada anak perempuan. Ini terjadi pada anak-anak ibu Zainab ${ }^{9}$ dimana anak laki-lakinya diberikan tugas mengisi air dan mengambil air ke tempat penampungan air, kemudian biasanya membantu bapaknya ke ladang. Anak perempuan biasanya tugasnya membereskan rumah seperti cuci piring, menyapu, dan membantu ibu di rumah. Anak laki-laki banyak membantu ayahnya di ladang dan anak perempuan banyak membantu ibunya di rumah. Menurut pengakuan ibu Zainab yang memiliki 6 orang anak ini bahwa dia merasa sangat dibantu oleh anak-anaknya, karena mereka semua mengerjakan pekerjaan rumah.

Bagi anak-anak ini pembagian kerja ini juga terkadang menimbulkan pertengkaran-pertengkaran antara kakak dan adik. Meskipun terkadang anak-anak ini tidak mutlak harus mengerjakan semua pekerjaan tersebut. Konflik yang berupa pertengkaran ini sering terjadi pada kakak dan adik, kakak yang punya pekerjaan lebih banyak dari pada adiknya sering mengeluh dan

${ }^{9}$ Seorang Ibu rumah tangga yang memiliki enam orang anak. Ibu ini adalah salah satu warga etnik Tamiang yang tinggal di desa Paya Udang. 
marah-marah mengerjakannya apalagi bila ia melihat adiknya hanya bermain-main. Kejadian lain yang membuat mereka bertengkar karena si adik terkadang melakukan pekerjaannya tidak maksimal, sering hasil pekerjaannya tidak bersih. Ini dapat dilihat dari kerapian ketika membereskan tempat tidur dan kamar, sewaktu adiknya membersihkan kamar ada barang kakaknya yang tidak kelihatan maka ini akan menimbulkan keributan dirumah. Biasanya salah satu dari mereka pasti ada yang menangis. Pertengkaran lebih sering terjadi antara anak perempuan, sedangkan pada anak laki-laki dan perempuan yang bersaudara tidak terlalu sering terjadi.

Biasanya apabila sudah bertengkar seperti itu maka tidak ada diantara mereka yang mau mengerjakan tugas dan biasanya ibunya yang marah-marah. Hal ini tidaklah berlangsung terlalu lama, apalagi mereka kemudian diizinkan bermain. Anak laki-laki jarang sekali bertengkar hanya karena pekerjaan rumah. Tetapi pertengkaran terjadi ketika ada perebutan mainan antara sesama saudara lelakinya. Selain karena mainan, biasanya yang dipertengkarkan masalah pekerjaan membantu bapaknya ke ladang. Biasanya bila bapaknya sudah marah maka mereka tidak akan ada lagi yang berani membantah karena mereka sangat takut pada bapaknya dari pada pada ibunya. Walaupun mereka bertengkar tugas mereka tetap juga mereka kerjakan dengan baik dan pertengkaran ini tidak berlangsung lama, beberapa jam kemudian biasanya langsung baikan lagi.

Bila anak-anak tidak mengerjakan tugas rumahnya maka ibu atau pun bapaknya akan marah. Biasanya ibu akan bilang " tidak usah kerjakan kerjaanmu nanti tidak akan ibu belikan baju, atau mainan sama kamu". Biasanya kalau sudah dibilang begitu pasti anak-anak takut dan cepat-cepat mengerjakan kerjaannya. Atau hal lain yang dikatakan seperti "tidak usah kerjakan nanti ibu kurung dikamar mandi" terkadang ibu mendiamkan saja tanda sudah amat marah. Ini dilakukan bila sudah tidak bisa lagi diberitahu atau dinasehati dan apabila mereka jadi bertengkar hanya karena tugas rumah mereka. Biasanya anak-anak tidak mau mengerjakan tugas rumahnya dengan alasan ada PR dari sekolah. Bila sudah ini alasannya maka ibu terkadang tidak akan menyuruh mereka dan mengerjakannya sendiri. ${ }^{10}$

Anak laki-laki dan perempuan sering bermain bersama setiap hari, ketika mereka bermain ada juga yang terlihat anak laki-laki ikut bermain masak-masakan dengan anak perempuan atau anak laki-laki ikut bermain boneka-bonekaan, begitu juga sebaliknya. Hal ini sesekali terlihat tetapi sebagai orang tua tidak ada tindakan yang berlebihan yang dilakukan, hanya bilang "mainlah apa yang punyamu, tidak boleh anak perempuan main kelereng (guli) dan sebaliknya". Bila sudah dibilang seperti itu maka ada juga yang langsung mamatuhi tetapi ada juga yang tidak, mungkin karena anak-anak menganggap hal seperti ini biasa. Mereka dapat bermain apa saja yang mungkin mereka inginkan. Biasanya bila terjadi seperti itu sudah menjadi hal biasa yang terlihat jadi bukan sesuatu kejanggalan.

\footnotetext{
${ }^{10}$ Wawancara dengan ibu Nur' Aini.
}

Antara kakak dan adik juga sangat dekat, dengan jarak umur yang tidak terlalu jauh sehingga dapat tumbuh bersama. Ditambah lagi pengajaran dari orang tua untuk menghormati dan menyayangi kakak atau adik sendiri. Di Desa Payah Udang dan Desa Sekerak Kanan masih dijumpai keluarga yang memiliki banyak anak dan ada juga yang sedikit. Dijumpai juga antara kakak dan adik bertengkar ketika bermain memperebutkan mainan atau karena adik kalah bermain dengan kakaknya. Tetapi biasanya sebentar saja mereka akan rujuk kembali dan bermain kembali. Inilah hubungan yang terlihat diantara keluarga etnis Tamiang yang masih dekat dan ini juga dipengaruhi oleh kondisi lingkungan sekitarnya, yang masih memegang adat istiadat Tamiang.

Penilaian terhadap sopan santun anak dapat dilihat dari sopan santun terhadap orang lain. Setiap orang tua menginginkan anaknya memiliki sopan santun yang baik kepada orang lain, membantu orang lain sehingga banyak orang yang suka dan menyayanginya. Biasanya bila si anak baik maka banyak orang yang suka padanya, dan biasanya mereka juga akan memuji ibunya. Ini sebuah kebanggaan bagi orang tua bila banyak orang yang sayang pada anaknya. Menurut ibu Khadijah ${ }^{11}$ bila anak berkelakuan baik dan menyenangkan hati orang maka terkadang diberi pujian melalui kata-kata, seperti "ini anak mamak yang baik budi selalu buat hati orang tua senang" ataupun diberi hadiah berupa mainan. Bila anak baik maka hadiah dan pujian tidak hanya datang dari orang tuanya tetapi juga dari orang yang dibuatnya senang.

Seorang anak sangat senang dipuji dan juga disayang oleh orang lain. Apalagi bila ketika dipuji ada temannya yang mendengar maka ini akan menjadi kebanggaan tersendiri bagi dia. Lebih lagi bila anak diberikan hadiah maka lebih besar pula rasa senangnya. Oleh karena itu maka si anak akan melakukan hal yang sama untuk menyenangkan hati orang dan mendapatkan hadiah. Menurut ibu Zainab memberikan pujian bagi si anak juga menjadi salah satu cara yang baik untuk mendidik anak menjadi lebih baik. Anak tidak boleh selalu dimarahi bila ia berbuat nakal, harusnya dia dinasehati dan diberitahu hal yang baik. Bila anak langsung dimarahi bisa-bisa anak menjadi trauma dan akan berbuat nakal terus. Sebagai orang Tamiang maka dari kecil anak-anak Tamiang sudah diajari sopan santun dan tata krama, ini tidak hanya diajarkan oleh orang tua tetapi juga dalam agama. Dari sejak kecil anak sudah diajarkan sholat dan mengaji oleh sebab itu ketika mengaji maka anak juga mendapatkan pelajaran agama. Dari situlah anak mendapat pelajaran agama dan membantunya menjadi anak yang baik, Walaupun ada juga anak menjadi anak yang nakal. Oleh sebab itu ilmu agama sangat penting bagi moral si anak.

Setiap anak adalah kebanggaan buat orang tuanya, setiap orang tua ingin anaknya membawa nama keluarganya. Sebagai salah satu contoh adalah etnik bangsa Batak, bagi orang Batak anak laki-laki pertama akan membawa marga bapaknya sehingga dari sejak kecil

${ }^{11}$ Salah satu warga etnik Tamiang yang tinggal di desa Kota Lintang 
sudah diajari akan adat Batak itu sendiri. Tidak hanya etnik bangsa Batak yang demikian. Menurut bapak Syarifuddin Ismail ${ }^{12}$ etnis Tamiang juga demikian. Sejak kecil anak juga diajari adat istiadat Tamiang. Seorang anak Tamiang dikatakan sebagai anak Tamiang adalah dengan melihat dialek Tamiang yang tentunya berbeda dengan dialek Aceh (karena berbaur dengan etnis Aceh) ketika berbicara dengan orang lain. Seorang anak dikatakan anak Tamiang adalah jika anak juga telah mengerti dan menerapkan budaya-budaya Tamiang. Biasanya setiap anak dari mulai beranjak remaja telah diajarkan budaya-budaya Tamiang, yang paling terlihat adalah dari dialek berbicaranya.

Selain itu, terkait dengan hubungan orang tua dengan anak, terutama yang berhubungan dengan model pengasuhan, maka para orang tua etnik Tamiang pada umumnya menganut pola asuh demokratis. Orang tua memberikan kebebasan kepada anak untuk berkreasi dan bereksplorasi. Namun demikian, orang tua memberikan batasan-batasan dalam arti otoriter terutama menyangkut hal-hal adat istiadat dan agama. Misalnya, orang tua sangat menekankan kepada anak dalam mengaji alQur'an, menjaga kesopanan, dan lain-lain.

\section{Hubungan Anak dalam Keluarga Luas}

Pada masyarakat etnis Tamiang dari mulai turun tanah anak sudah diajarkan untuk bersosialisasi, selain dengan kerabat dekat ayah dan ibu juga para tetangga. Biasanya setelah turun tanah pada sore hari selesai mandi sianak oleh neneknya dibawakan(ditandangkan) atau dibawa jalan-jalan keluar rumah. Ditandangkan biasanya kerumah keluarga atau jiran tetangga yang terdekat dan terletak disebelah hulu. Keluarga yang ditandangi atau dikinjungi menyambut anak yang datang tersebut dengan resam mencicipi, kalau laki-laki dengan garam dan kalau anak perempuan dengan gula.

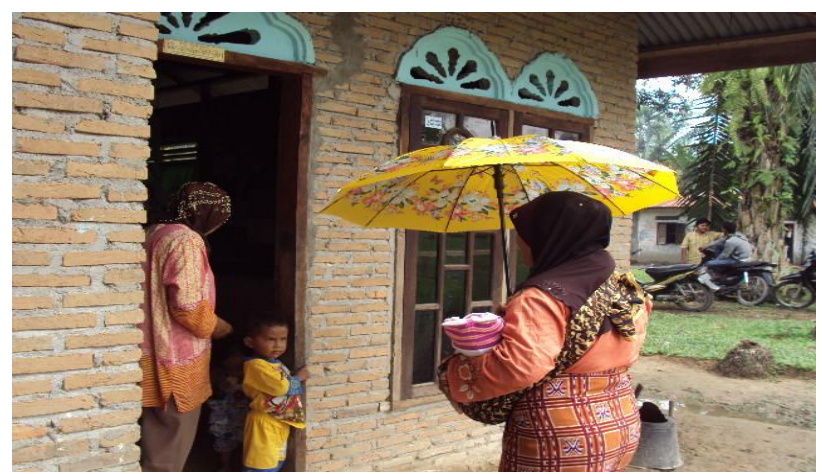

Gambar 3: Bayi yang sudah dituruntanahkan kemudian biasanya dibawa oleh neneknya keliling bertandang ke rumah-rumah jiran.

Ketika sianak hendak dibawa pulang, ibu rumah yang ditandangi tadi haruslah memberikan hadiah (memanja jametook) kepada anak tersebut. Kalau tidak ada uang boleh juga sebutir telur ayam kalau inipun tidak ada haruslah disambilkan bambu atap lalu di genggam ketangan anak itu dengan mengucapkan sepatah

${ }^{12}$ Ketua Majelis Pertimbangan Pendidikan Tamiang kata "ingatlah yang ada, janganlah kau lupakan andung(makjik) doaku menyertaimu”.

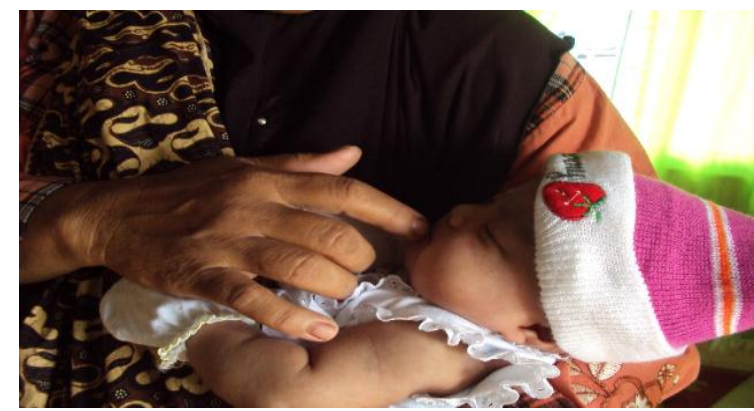

Gambar 4: Adat Resam mencicipi (anak laki dicicipkan garam sedangkan anak perempuan dicicipkan gula.

Dalam hal resam mencicipi bayi ini, terkadang orang tua menyerahkan atau meminta orang yang dianggap alim, atau imam kampung yang dipandang alim. Hal ini dimaksudkan, agar kelak si anak menjadi orang alim juga, terpandang dan baik budi pekertinya. Upacara nyecapi ini terkadang juga dimulai dengan mengucapkan "Bismillahirrahmanirrahim, biar manih lidah, panjang umor, mudah rejeki, bergune kak masyarakat, biar taat beribadah". Selain itu juga, adat ini bertujuan untuk member rasa kepada bayi agar nanti tidak canggung hidup dalam masyarakat dan tidak malas bekerja.

Pada dasarnya, proses resam mencicipi bayi ini adalah sebuah pengharapan dari orang tua kepada anaknya kelak menjadi orang yang dapat dibanggakan oleh orang tuanya, menjadi anak yang berbudi baik dan rajin. Proses pengharapan inilah kemudian dikemas dalam suatu proses adat istiadat.

Kepercayaan di Tamiang dalam hal menandangkan anak, mula pertama haruslah kearah hulu dari rumahnya, kemudian seterusnya barulah boleh ditandangkan kearah-arah yang lain, setidaknya sampai bayi tersebut berumur enam bulan. Setiap rumah yang mendapat tandangan (kunjungan) anak sewaktu pulangnya haruslah dihadiahi (digenggamkan) kedalam tangannya, jangan sampai ia pulang kosong takut anak tersebut berputus asa, karena keyakinan orang-orang Tamiang bahwa anak itu selalu disertai oleh malaikat.

Untuk menandang bayi sesudah yang pertama, biasanya sinenek bersama anak dan anak menantunya silih berganti mengunjungi rumah-rumah keluarganya dan jiran terdekat. Kesemua pembiasaan yang dilakukan pada anak dari mulai sejak bayi pada lingkungan keluarganya dan tetangganya menjadikan anak-anak Tamiang dekat dengan keluarga dan juga jiran tetangga, serta lingkungan masyarakat tempat tinggalnya. Hingga ketika mereka menginjak usia remaja dan dewasa hal ini menjadi sebuah tradisi, juga terjalin hubungan yang akrab.

Dalam menanamkan nilai-nilai dan pendidikan agama, para orang tua menurut bapak Syarifuddin Ismail ${ }^{13}$ memasukkan anak-anaknya sejak usia 4-7 tahun untuk mengaji, selain belajar ke sekolah. Adalah suatu

${ }^{13}$ Ketua majelis Pertimbangan Pendidikan Tamiang 
keaiban apabila sianak telah tahu malu tapi belum diserahkan mengaji pada imam kampung/meunasah. Pada jaman dahulu sepanjang resam adat Tamiang menyerahkan anak mengaji haruslah menyediakan:

1. Pulut kuning + ayam panggang + pisang raja seikat + telur ayam rebus sebutir

2. Beretih sepinggan

3. Rotan sega sepanjang lebih kurang 1 hasta, separuh ujungnya dibelah tujuh pangakalnya dan ditajami

4. Surat Jus Amma beserta rehalnya

5. Sirih sejorong

Syarat-syarat itu akan berbeda bila anak chatab juz Amma juga chatab Al-quran. Dimana tentunya orang tua akan kembali membawa syarat-syarat yang ditentukan pada imam kampung.

Seorang anak laki-laki dianggap sudah dewasa ketika dia sudah "akil baliq", pada masa ini seorang anak laki-laki dianggap sudah dapat memikul tanggung jawab yang lebih besar dari keluarga. Ketika anak sudah bekerja maka tanggung jawab itu lebih besar diberikan orang tua. Karena dianggap sudah memiliki kedewasaan dan sudah dapat memimpin di dalam sebuah keluarga. Maka tanggung jawab sang anak juga semakin bertambah. Tanggung jawab kepada keluarga akan lebih terlihat ketika orang tuanya sudah tidak dapat lagi bekerja maka kebutuhan keluarga ditanggung oleh anaknya.

Pada usia 13 sampai 14 tahun anak - anak di Desa Paya Udang dan Desa Sekerak kanan sudah terlihat ikut bekerja membantu orang tuanya sepulang sekolah, itupun jika anak-anak sekolah tapi jika anak-anak tidak sekolah maka mereka sudah ikut bekerja sejak pagi hari. Biasanya pekerjaan yang mereka lakukan adalah mengambil pasir di sungai ataupun mencari ikan. Bila mereka memiliki sawah ataupun ladang,anak-anak diajarkan untuk bekerja bersawah dan berladang. Jadi pada usia tertentu anak-anak sudah diajarkan kemandirian oleh orang tuanya ditambah lagi dengan tuntutan ekonomi di dalam keluarga. Anak laki-laki memiliki tanggung jawab yang lebih besar dalam keluarga sehingga sejak mulai beranjak remaja sudah ditanamkan nilai tanggung jawab tersebut.

Sedangkan anak perempuan pada tahap kedewasaan maka orang tua mulai memikirkan jodoh anaknya apalagi bila anak perempuannya tidak sekolah maka yang dipikirkan adalah jodoh anaknya. Ketika anak perempuannya sudah mulai didekati seorang laki-laki maka orang tua sudah menilai anaknya sudah beranjak dewasa dan sudah dapat menikah. Anak perempuan yang sudah bekerja juga dapat membantu orang tua memenuhi kebutuhan keluarga. Anak perempuan di Desa Paya Udang dan Sekerak Kanan banyak juga yang menikah di usia muda.

Istilah sapaan yang menjadi ciri khas pada orang etnis Tamiang selalu diajarkan kepada anak-anak mereka. Ini merupakan tradisi yang harus dilaksanakan dalam hubungan kekeluargaan. Istilah sapaan ini menjadi pengikat hubungan kekeluargaan mereka. Istilah sapaan dalam tradisi Tamiang tersebut juga mengekspresikan penghormatan dari orang yang muda kepada orang yang lebih tua.

Mengacu pada pandangan John W. M. Whiting Irvin L Child dkk (Danandjaja, 1989) terkait dengan pola pengasuhan anak, maka masyarakat etnik Tamiang, pada umumnya lebih cenderung pada beberapa pola asuh seperti;

1. Tingkah laku yang bersifat mempunyai rasa tanggung jawab (responsibility)

Pola asuh metode ini mengunggulkan sifat untuk menyelesaikan pekerjaan yang menjadi tugas pokoknya. Melakukan aktifitas sesuai dengan semestinya, tidak melakukan pekerjaannya berdasarkan kesenangan saja tanpa prosedur atau norma-norma yang ada dalam melakukan pola asuh terhadap anak, sehingga pekerjaan itu selesai sesuai dengan norma-norma yang berlaku. Dengan demikian optimalisasi dalam menanamkan norma-norma pola asuh sesuai dengan tanggung jawab terhadap apa yang dilakukannya.

Hal ini tampak pada bagaimana orang tua bertanggung jawab dalam mengasuh anak-anak mereka. Sebagai contoh adalah bahwa orang tua etnik tamiang sangat memperhatikan kegiatan dan perilaku anak-anak mereka sehari-hari. Dalam hal pengasuhan anak mereka juga kurang memberikan kepercayaan kepada orang lain untuk mengasuh anaknya. Mereka lebih mengutamakan mengasuh anak mereka dengan sendirinya. Selain itu juga, pola pengasuhan model ini, terlihat dari bagaimana para orang tua etnik Tamiang mendidik anak-anak mereka untuk memiliki rasa tanggung jawab terhadap apapun yang mereka perbuat. Sebagai contoh, ketika anak disuruh untuk membersihkan rumah, maka mereka harus menyelesaikan pekerjaan tersebut. Ini sebagaimana yang disebutkan oleh Pak Sarmidin ${ }^{14}$ yang menyatakan bahwa jika anak diamanahkan suatu pekerjaan, maka orang tua akan memberikan sanksi jika hal itu tidak dilakukannya. Hal ini menurut beliau dimaksudkan sebagai upaya menanamkan rasa tanggung jawab pada diri anak tersebut.

2. Tingkah laku yang bersifat ingin mencapai sesuatu yang lebih baik (achievement-oriented behavior)

Yaitu pola asuh yang menunjukkan bahwa perilaku yang ditampilkan lebih menonjol prestasi yang terbaik. Metode ini mengajarkan untuk senantiasa membudayakan prioritas yang lebih baik. Memberikan pola asuh tersebut dengan memberikan contoh-contoh sifat yang berupaya untuk mendapatkan yang terbaik dari yang lainnya. Berorientasi kepada perilaku yang lebih baik.

Pola ini tampak pada bagaimana para orang tua mendidik anak-anak mereka. Para orang tua selalu mengajarkan kepada anak-anak agar selalu memiliki sifat dan perilaku yang baik kepada orang lain. Hal ini menunjukkan bahwa ada upaya orang tua untuk senantiasa menonjolkan hal-hal yang lebih baik pada kehidupan.

${ }^{14}$ Pak Sarmidin adalah Kepala Sekolah Dasar di Desa Sekerak Kanan. 
3. Tingkah laku yang bersifat patuh pada orang tua atau pemimpin (obidience)

Pola ini mengajarkan kepada anak agar memahami posisi kehidupan dalam keluarga, memahami siapa yang harus di hormati dan disayangi dan siapa pula yang memiliki hak untuk mengayomi, memelihara, melindungi dan memberikan kasih sayang dan perhatian. Sehingga dengan posisi kedudukan ini memudahkan untuk menerapkan pola asuh kepada anak-anaknya. Karena dipahaminya siapa yang harus disayanginya dan di hormatinya. Selain itu metode ini menunjukkan siapa diantara keluarga itu lebih banyak mempengaruhi untuk dapat mencapai tujuan kehidupan keluarga. Berarti memahami siapa yang menjadi pemimpin dalam keluarga tersebut. Itu artinya orang tua lah yang harus diperhatikan perilakunya dalam memberikan pola asuh kepada anak-anaknya.

Salah satu bentuk yang mengindikasikan pola ini dalam pengasuhan anak Tamiang yaitu kuatnya adat Tamiang dalam mendidik anak-anak mereka dalam hal panggilan keluarga dan kepada orang yang lebih tua dari mereka. Selain itu, peran ayah dan ibu bisa dikatakan bukan peran yang paling utama dalam hal pengasuhan. Atok atau nenek dalam masyarakat Tamiang juga mempunyai kedudukan penting baik itu dalam hal pengasuhan anak, terutama dalam hal mengambil kebijakan keluarga terkait dengan masalah anak dalam keluarga. Hal ini sebagaimana yang diutarakan oleh Bapak Hasnan yang tinggal di desa Sekerak Kanan.

4. Tingkah laku yang bersifat gemar menolong orang lain yang sedang mengalami kesukaran (nurture).

Pola ini mengajarkan kepada anak untuk memiliki sifat perhatian kepada orang lain (Emphaty). Memahami apa yang dirasakan oleh orang lain, sehingga mendorong orang tersebut untuk membantu orang yang mengalami kesulitan.

Pola pengasuhan ini terlihat pada bagaimana orang tua senantiasa menanamkan rasa peduli terhadap sesama. Bagaimana orang tua selalu menanamkan rasa kepekaan sosial dan rasa berbagi dengan sesama. Misalnya, ketika anak dibelikan jajanan atau kue-kue ringan di saat ia ada bersama teman-temannya, maka orang tua selalu mengajarkan untuk memberi sebagian kepada teman bermainnya. Perbuatan ini tentunya merupakan upaya orang tua dalam menanamkan rasa kepedulian sosial kepada anak sejak dini.

Dilihat dari beberapa hal di atas, maka dapat disimpulkan bahwa ada empat hal yang sangat penting terkait dengan pembentuka karakter anak atnik Tamiang yang ditanamkan oleh orang tua yaitu;

1. Internalisasi nilai-nilai memiliki rasa tanggung jawab terhadap setiap yang dilakukan oleh anak dan yang diamanahkan kepadanya.

2. Pendidikan kepada anak tentang pentingnya perubahan diri untuk senantiasa menuju kepada segala sesuatu yang baik dalam segala hal.
3. Pembentukan karakter anak agar memiliki rasa hormat dan patuh kepada orang tua dan keluarga besar lainnya.

4. Penanaman nilai-nilai kepedulian sosial kepada anak, agar kelak anak menjadi orang yang peduli kepada orang lain, terutama mereka yang membutuhkan.

\section{Perubahan Pola Asuh Anak Pada Etnik Tamiang Pengimplementasian Adat Istiadat}

Di atas telah dijelaskan bagaiaman etnik Tamiang mengasuh anak-anak mereka yang cendrung lebih menekankan pola asuh secara tradisional, karena mengedepankan adat istiadat dan kebudayaan etnik Tamiang. Namun demikian terjadi perubahan pada pola asuh tersebut. Akan tetapi, perubahan yang terjadi tidak terlalu signifikan, perubahan itu hanya bersifat pada tataran pola pikir atau cara pandang terhadap pengimplementasian adat istiadat yang dijalankan oleh kelompok etnik Tamiang.

Berdasarkan hasil wawancara dengan Dra. Idawati ${ }^{15}$ menyatakan bahwa telah terjadi perubahan pada pola asuh etnik Tamiang pada saat ini. Salah satu perubahan yang terjadi adalah tentang pemikiranpemikiran terhadap pantangan-pantangan yang diberlakukan sesuai tradisi etnik Tamiang. Jika dahulu mereka sangat mempercayai pantangan-pantangan tersebut dan melaksanakannya sesuai ketentuan adat istiadat mereka, maka saat ini penerapan pantanganpantangan tersebut hanya dijalankan oleh beberapa orang saja. Biasanya yang masih percaya dan menjalankannya hanya orang-orang yang menurut penulis dapat diklasifikasikan orang-orang yang masih bersifat tradisional. Artinya mereka masih berada di sekitar lingkungan yang mana para orang tuanya ataupun orangorang yang masih dihormati menjalankan dan sering sekali pengontrol jalannya suatu tradisi.

Para ibu-ibu sekarang ini, khususnya generasigenerasi yang menikah muda tidak begitu percaya kepada pantangan-pantangan yang berkaitan dengan masa kehamilan dan sebenarnya telah menjadi bagian dari kebudayaan mereka. Salah satunya adalah seperti tidak boleh duduk ditanah tanpa alas, tidak boleh duduk di dekat pintu ataupun tidak boleh memotong rambut. Menurut pengakuan mereka bahwa kepercayaan terhadap hal-hal tersebut diakibatkan oleh pola pikir orang-orang tua mereka dahulu yang masih sangat tradisional. Menurut mereka ketentuan-ketentuan pantangan dan akibatnya bagi calon ibu adalah upaya orang tua untuk membentuk perilaku yang baik kepada ibu dan khususnya calon bayinya. Namun memang saat ini beberapa ketentuan itu tidak lagi dijalankan karena terdapat perbedaan pola pikir antara orang tua dan anak-anak mereka yang baru merasakan hamil. Menurut mereka wajar wanita hamil tidak boleh duduk ditanah karena tanah itu kan kotor sedangkan untuk duduk di dekat pintu itu akan membuat orang susah untuk lewat. Menurut ibuibu bila mereka tidak memotong rambut, akan terasa

15 Ibu Idawati adalah Kepala Sekolah SMA 2 Percontohan dan merupakan tokoh masyarakat Tamiang 
panas dan rambut yang panjang sangat merepotkan ketika hamil. Jadi tidak ada hubungannya dengan semua ketakutan-ketakutan yang dikatakan orang tua dahulu.

Selain alasan-alasan yang bersifat rasional tersebut, ada juga alasan-alasan situasi yang mereka rasakan, dimana banyak para ibu yang bekerja di luar rumah, bila mereka tidak memotong rambut mereka tentu sangat panas dan merepotkan. Menurut pengakuan informan yang sedang hamil saat ini, dengan rambut yang tidak panjang selain tidak merepotkan juga mereka tidak gerah dan terasa nyaman. Sehingga ini sangat baik untuk perkembangan dan kesehatan bayinya. Pemikiranpemikiran seperti ini muncul karena kebanyakan generasi anak-anak muda yang sedang hamil di Desa Paya Udang dan Desa Sekerak kanan tersebut lebih banyak berkonsultasi kesehatan kehamilannya dengan bidan desa. Sehingga ini juga menjadi salah satu faktor perubahan pola pikir antara orang tua dahulu dengan calon orang tua saat ini yang didominasi oleh generasi muda. Sedangkan orang tua dahulu ketika hamil hanya berkonsultasi kesehatan kehamilan dengan seorang dukun beranak saja.

Perbedaan pola pikir ini juga terlihat pada kepercayaan terhadap makhluk halus. Bagi sebagian ibuibu mahluk halus itu memang ada dan bisa mengganggu apabila kita tidak menjaga diri dengan baik berupa perilaku dan cara berbicara ketika kita sedang pada masa kehamilan. Sedangkan menurut sebagian ibu-ibu yang lain menyatakan bahwa sebenarnya mahluk halus itu tidak ada, itu hanya merupakan perasaan kita saja yang terlalu takut. Biasanya seorang ibu akan lebih sensitif sehingga suka mengira-ngira dan berpikir yang tidaktidak.

Sebagian ibu-ibu ini merasa bahwa pemikiran yang ada dalam kepala kita inilah yang terkadang menimbulkan ketakutan-ketakutan terhadap sesuatu. Ketika seseorang mengalami kesulitan dalam proses persalinannya maka itu tidak dikarenakan melanggar pantangan-pantangan yang ditetapkan dan dilegitimasi dalam kepercayaan masyarakat etnik Tamiang. Kalaupun ada yang susah melahirkan maka itu memang karena kondisi kesehatan si ibu. Berdasarkan pengakuan mereka sampai saat ini tidak ada yang susah melahirkan karena makhluk halus. Oleh sebab itu setiap bulannya si ibu harus rajin periksa ke bidan desa agar diketahui perkembangan bayi dan kesehatan si ibu. Maka apabila seperti itu ibu dan anak akan selamat saat melahirkan. Hal ini yang membuat sebagian ibu-ibu tidak lagi percaya pada mahluk halus seperti kuntilanak yang dapat mengganggu kehamilan ibu.

Bagi para ibu-ibu yang masih percaya akan adanya mahluk halus biasanya mereka akan tetap menggunakan tangkal dan tidak akan keluar rumah pada saat manghrib. Menurut kepercayaan mereka pada saat maghrib merupakan waktu peralihan antara siang dan malam. Pada masa peralihan inilah para mahluk halus berkeliaran dan dapat mengganggu orang-orang yang berada di luar rumah, khususnya anak-anak dan orang hamil.

Pada saat hamil seorang ibu disarankan untuk lebih sering mengaji dan membaca Al-Qur'an agar terhindar dari mahluk-mahluk apapun yang ingin menggangu. Pada saat hamil sorang ibu tidak boleh pergi sendirian, oleh sebab itu harus senantiasa ditemani oleh suami ataupun sanak saudara lainnya. Menurut orang tua darah seorang ibu yang sedang hamil itu wangi sehingga sering diganggu oleh mahluk halus. Tetapi yang mempercayai hal ini tidaklah semuanya. Biasanya ibu-ibu yang sudah memiliki pendidikan yang lebih tinggi tidak akan percaya terhadap sebab akibat dari gangguanganggan makhluk halus tersebut. Faktor lainnya adalah karena perkembangan zaman yang sudah lebih moderen yang memungkinkan mereka melakukan perbandinganperbandingan dengan hal-hal yang bersifat realistis dan logis hal ini dikarenakan tingkat pendidikan mereka yang semangkin tinggi.

Meskipun ada ibu-ibu yang tidak mempercayai mahluk halus tersebut tetapi ibu tersebut tetap meggunakan tangkal dan ini karena orang tua yang mengharuskan memakai tangkal juga untuk menghargai orang tua maupun mertua. Menurut bidan desa yang diwawancarai hampir semua ibu-ibu yang hamil memiliki tangkal yang terkadang diselipkan dibaju ataupun dikantongi ini terlihat ketika bidan tersebut memeriksa kandungan si ibu. Apabila ditanya maka ibu-ibu menjawab ini penangkal buat roh-roh halus. Menurut para ibu apabila seorang ibu tidak menggunakan tangkal ketika hamil maka akan dianggap sombong dan biasanya pandangan orang tua menjadi negatif terhadap ibu tersebut karena dianggap sok pintar. Orang tua sekitar masih sangat percaya kepada tangkal yang dapat menjaga ibu yang sedang hamil. Dan apabila terjadi sesuatu pada si ibu maka orang dilingkungan sekitar akan menyalahkan si ibu karena tidak menggunakan tangkal dan biasanya mereka kurang peduli terhadap ibu tersebut oleh karena kesombongan si ibu tersebut yang tidak menuruti perkataan orang tua.

Alasan para ibu yang tidak mengunakan tangkal adalah karena mereka menganggap tidak masuk akal menggunakan tangkal tersebut ada yang berkata "masak gunting / paku dan lainnya bisa menjaga manusia, tidak masuk akal" alasan lain ada juga karena mereka menganggap itu dangat merepotkan bila berpergian kemana-mana.

Biasanya yang mendorong para ibu untuk menggunakan tangkal adalah kepercayaan terhadap keselamatan pada saat melahirkan dalam keadaan yang sehat. Selain itu juga merupakan anjuran dari orang tua yang harus diikuti dan dilaksanakan. Oleh sebab itu maka setiap tradisi ini juga haruslah dibuat agar semua dalam keadaan selamat. Tangkal tersebut tidak dapat digantikan dengan benda lain karena itu sudah dari orang tua terdahulu dan sudah dianggap ampuh untuk menjaga ibu hamil. Mereka menganggap tangkal tersebut sudah cukup berkhasiat bagi ibu hamil. Tangkal tersebut dibuat oleh ibu mertua ataupun ibu kandung si wanita juga. Ataupun minta dibuatkan orang tua yang sudah dianggap lebih mengerti.

Malahan para ibu-ibu yang memiliki anak bayi lebih percaya dan takut "kesapoh" yaitu suatu keadaan dimana sibayi diganggu atau disenggol makhluk halus. Yang lebih dramatis bila anak bayi kesapoh bayi tersebut 
akan menangis sepanjang malam tanpa henti, juga badannya akan panas tentunnya hal ini mengakibatkan sibayi kurus atau badannya susut. Kondisi ini banyak terjadi di Desa Paya Udang dan Desa Sekerak, oleh sebab itu setiap ibu sangat hati-hati menjaga anaknya dan sangat selektif dalam bepergian kesatu tempat, ditakutkan anaknya akan kesapoh berasal dari orang yang ingin berbuat jahat atau mencari ilmu hitam.

Dalam pola asuh yang lain misalnya seperti pembedungan masih dilakukan para ibu-ibu di Desa Paya Udang dan Desa Sekerak sampai sekarang. Ini dikarenakan karena hal ini merupakan perlindungan bagi bayi dan juga untuk memberikan kenyamanan baginya. Perubahan yang terjadi pada pengasuhan anaknya terjadi pada proses pengasuhan anak-anaknya. Ini dapat dilihat dari keluarga yang bapak dan ibunya bekerja diluar rumah. Pada keluarga tersebut maka anak-anaknya diasuh oleh seorang pengasuh atau penjaga bayi. Selain dijaga oleh pengasuh maka apabila kedua orang tuanya bekerja anak bisa titipkan pada neneknya atau saudara dari pihak ibu ataupun ayahnya. Seperti pada kasus ibu Juniati yang bekerja sebagai guru, anak dijaga oleh orang yang sudah dipercaya untuk menjaga mereka. Setelah pulang kerja maka si pengasuh juga boleh pulang ke rumahnya. Biasanya mereka diasuh pada usia-usia satu tahun atau terkadang kurang dari satu tahun. Tetapi apabila usianya kurang dari satu tahun ibu belumlah terlalu percaya sehingga usia anak masih bayi dijaga oleh neneknya dan pada usia satu tahun baru mulai diberikan kepada pengasuh.

Perubahan lain yang terlihat dalam pola asuh masyarakat Tamiang di Desa Paya Udang dan Desa Sekerak kanan salah satunya adalah pengasuhan anak. Selain diasuh oleh orang tuanya sendiri, biasanya mereka menyerahkan pengasuhan anak kepada pengasuh atau kepada keluarga dekatnya. Akibat dari system pengasuhan ini ada beberapa kebiasaan yang tidak lagi dilakukan pada anak seperti mendodoi yaitu kebiasaan para ibu yang menidurkan anaknya dulu sambil mengayun anaknya dengan menyanyikan lagu-lagu agar anak cepat tidur. Biasanya seorang ibu sangat senang melakukannya dan butuh waktu setengah jam sampai satu jam untuk mendodoi bayi.

Mendodoikan anak tidak hanya dengan menyanyikannya lagu-lagu saja, tetapi terkadang juga sambil menggerakkan ayunan dimana anak diletakkan didalam ayunan tersebut. Anak-anak biasanya didodoikan pada siang hari setelah anak lelah bermain, atau sedang menangis disebabkan karena sesuatu hal. Ayuanan yang digunakan terbuat dari sehelai kain panjang yang diikat dengan sebuah tali ke sebuah kayu yang letaknya horizontal yang bisa didapatkan di atas diantara dindingdinding rumah.

Mendodoi dilakukan si ibu atau kakak perempuan dari seorang anak. Lagu yang dinyanyikan dalam dodo $i$ seiring dengan gerak ayunan yang lembut, sehingga hal ini menghasilkan gerak dan irama nada yang sejajar dan yang begitu menghanyutkan bayi ke peraduan mimpinya. Alunan lagu-lagu yang dinyanyikan diringi gerak ayunan akan membuat sang anak terbuai. Mendodoi merupakan kebiasaan yang diberikan kepada anak sejak dia mulai ditidurkan diayunan, maka tidak ada anak yang mau ditidurkan tanpa lebih dahulu didodoi. Anak akan berontak dari ayunan bila dia tidak didodoikan dan dodoian itu sendiri baru dapat dihentikan bila anak benarbenar telah tidur.

Hal-hal seperti mendodoi dulu sangat sering dilakukan tetapi sekarang tidak ada lagi ibu yang melakukannya. Menurut mereka anak sekarang tidak lagi dilakukan karena kesibukan orang tuanya yang bekerja diluar rumah. Jadi bila ingin menidurkan anaknya hanya dengan meletakkannya saja ditempat tidur sekali-kali badannya dibelai secara perlahan supaya cepat tidur.

Perubahan yang lain terlihat pada upacara-upacara menyambut kelahiran bayi. Tidak semua keluarga pada etnik Tamiang yang melaksanakannya, hal ini mungkin disebabkan oleh dana dan juga takut repot. Perubahan lain yang terlihat adalah cara mengasuh anak tidak lagi bersifat tradisional tetapi sudah mulai mengikuti perkembangan jaman. Hal ini tentunya disebabkan oleh kemajuan teknologi juga informasi-informasi yang masuk. Meskipun dibeberapa keluarga masih dilakukan tetapi biasanya itu terjadi pada keluarga yang masih kental dengan adat Tamiangnya. Perubahan cara mengasuh anak mengalami perubahan salah satu faktornya adalah saat ini sudah ada bidan desa yang selalu memberikan informasi bagi setiap ibu, bidan tersebut secara rutin datang ke Desa Paya Udang dan Sekerak Kanan, biasanya kunjungan ini dilakukan 2 kali dalam satu bulan. Pada saat bidan desa datang maka setiap ibu yang hamil datang memeriksakan kehamilannya demikian juga ibu lainnya datang membawa anaknya untuk diperiksakan seperti berat badannya dan imunisasi.

Peran orang tua sangatlah besar bagi seorang anak, bahkan seorang ibu memiliki tanggung jawab dari mulai mengandung sampai melahirkan anaknya bahkan merawatnya hingga dewasa. Demikian juga dengan peran seorang ayah yang bekerja mencari uang untuk memenuhi kebutuhan keluarganya. Menurut Sri salah satu anak dari bapak Abdullah dan ibu Siti Aisyah, mereka sangat menghormati orang tuanya dan sangat menyayanginya. "Orang tua kami senantiasa memenuhi kebutuhan kami, anak bapak dan ibu sebanyak tujuh orang dan semuanya tamat sekolah paling tidak tingkat SMA bahkan ada yang Sarjana”. Selain itu ibu dan bapak yang selalu memberikan nasehat kepada kami, kalau kami berbuat suatu tindakan yang salah maka ibu dan bapak yang memberikan nasehat dan yang selalu memberikan dukungan kepada anak-anaknya.

Tidak hanya itu saja, yang lebih besar adalah orang tua yang mengajarkan nilai-nilai agama kepada anak-anaknya, mengajarkan sholat dari mulai kecil, ibu yang mengajarkan mengaji setiap hari, mengajarkan berpuasa, mengajarkan baca dan tulis di rumah (selain disekolah juga) dan lain-lain. Anak-anak juga diajarkan tentang adat-istiadat Tamiang agar anak-anaknya tahu tentang adat dari etnisnya sendiri sehingga ketika merantau ke kampung orang tidak menjadi malu.

Oleh sebab itu, ayah dan ibu sangat berperan dalam pembentukan sifat dan karakter si anak. Apa yang dilakukan ayah dan ibunya biasanya merupakan contoh 
bagi anaknya, sehingga ibu dan ayah selalu menjaga sikap mereka agar selalu senantiasa baik dihadapan anak sehingga anaknya dapat tumbuh dengan memiliki karakter yang baik. Sering sekali yang terjadi di masyarakat bila si anak memiliki tingkah laku yang tidak baik maka yang dipersalahkan adalah orang tuanya yang dianggap tidak berhasil atau tidak baik dalam mendidik anak-anaknya. Sebaliknya demikian juga bila anaknya baik yang dipuji-puji juga orang tuanya.

Selain pembangunan karakter si anak, orang tua juga berperan dalam menerapkan nilai-nilai budaya Tamiang kepada anak-anaknya. Orang tua akan mengajarkan dan menerapkan nilai-nilai adat tersebut secara sederhana sejak anak di usia dini. Orang tua dan keluarga yang merupakan pranata pertama dalam menanamkan nilai-nilai budaya Tamiang. Apabila si anak tidak mengerti suatu adat maka orang yang pertama sekali ditanyai adalah orang tuanya sendiri. Oleh sebab itu maka orang tua senantiasa memberikan nasehat untuk sebuah acara-acara adat.

Selain ayah dan ibu orang yang juga berpengaruh besar terhadap perkembangan anak adalah nenek atau kakeknya. Nenek dan kakeknya juga memiliki pengaruh dalam mengasuh cucunya. Dalam keluarga ibu Siti Aisyah dan bapak Abdullah ${ }^{16}$, orang tua mereka tinggal dirumah mereka sehingga anak-anak dapat selalu bertemu dengan neneknya. Apabila kedua orang tuanya bekerja maka yang menjaga adalah nenek mereka. Oleh sebab itu nilai-nilai budaya dan sopan santun juga banyak diajarkan oleh nenek dan kakeknya. Biasanya nasehat yang diberikan berhubungan dengan rasa sopan santun dan adat Tamiang. Apabila nenek atau kakek melihat cucunya salah dalam adat atau kurang sopan santunnya maka nenek atau kakek akan memberikan nasehat.

Kemudian apabila anak sakit maka nenek selalu memberikan obat-obatan tradisional seperti apabila sakit demam maka nenek mengambil daun bunga raya (bunga kembang sepatu) lalu diremas-remas dengan air sampai berbuih dan ini disapukan ke badan si anak yang demam. Sedikit banyaknya nenek dan kakek berperan dalam keluarga karena tinggal bersama anak dan cucunya.

Ibu yang bekerja di luar rumah, akan mengggunakan jasa pengasuh anak seperti ibu Juniati yang bekerja sebagai guru sedangkan suaminya juga bekerja sebagai guru. Setiap hari mereka bekerja dan pulang hingga siang atau sore hari. Oleh sebab itu, anakanak sering ditinggalkan di rumah, apabila tinggal di rumah maka yang menjaga adalah pengasuh anak yang biasanya tinggal disekitar rumah.

Nilai-nilai penting yang diajarkan dalam adat budaya Tamiang adalah ajaran tentang agama Islam. Pengajaran ini terlihat juga pada pantun-pantun etnik Tamiang. Dalam sebuah syair pantun ada terdapat nilainilai agama Islam yang memuji nabi. Dalam sebuah pantun terkadang berisi ajaran-ajaran Islam yang harus dilakukan umatnya. Nilai-nilai agama Islam terlihat juga ketika bayi baru lahir yaitu bayi di " Azankan dan Qamatkan" (walaupun sebenarnya tidak hanya etnik

${ }^{16}$ Pasangan suami isteri etnik Tamiang yang tinggal di desa Payah udang. Sehari-hari bekerja sebagai petani.
Tamiang yang melakukannya tetapi setiap etnis yang beragama Islam)

Nilai agama sangat penting untuk diterapkan kepada anak-anak sejak usia dini. Ada banyak pesan moral yang terdapat dalam ajaran agama tersebut yang mampu membentengi si anak dalam pergaulannya seharihari. Oleh sebab itu setiap orangtua pasti akan memberikan ajaran agama itu sejak anaknya usia dini. Adapun yang dilakukan untuk memberikan ajaran Islam itu kepada setiap anak adalah salah satunya melalui mengaji Al-Qur'an di Mesjid bersama dengan ulama ataupun ustadz. Biasanya ini dilakukan pada sore hari sekitar pukul 4 sore hingga pukul 6 sore. Dalam mengaji ini anak juga diajarkan rukun-rukun Islam, dan segala sesuatu ajaran nabi Muhammad SAW tentang Islam. Setiap anak juga diajarkan akhlak yang baik oleh ustadz. Disini juga anak dilatih untuk mengerjakan sholat lima waktu dan hal-hal lain yang harus dilakukan seorang muslim. Selain itu setiap orang tua dari sejak kecil anaknya sudahlah di ajarkan untuk sholat.

Menurut ibu Juniati ${ }^{17}$ sangat penting bila anak melihat orang tuanya sholat berjemaah atau sholat bersama. Ini juga salah satu cara menerapkan nilai-nilai Islam tersebut karena jika si anak melihat langsung orang tuanya melakukannya maka ia akan juga mencontohnya. Biasanya seorang anak akan melakukan sesuatu yang juga dilakukan oleh orang tuanya. Hal inilah yang harus dijaga orang tua agar melakukan yang baik dihadapan anak.

Setiap anak diharuskan untuk belajar mengaji, dan biasanya belajar mengaji dilakukan sejak anak sudah bisa membaca dan menulis sekitar berumur 5 tahun. Meskipun ada juga anak berusia 3 tahun sudah dibiasakan mendengar ibunya mengaji agar anak terbiasa dengan ayat-ayat Al-Qur'an. Ibu Salmiati ${ }^{18}$ menganggap walaupun anak belum bisa mengikuti tetapi paling tidak ia pasti senang mendengar ayat-ayat Al-Qur'an yang sedang dibacakan.

Selain itu untuk menerapkan nilai-nilai agama Islam maka biasanya orang tua memasukkan anaknya ke sekolah-sekolah agama seperti madrasah. Orang tua menganggap madrasah adalah tempat yang baik bagi si anak untuk bersekolah karena akan diajarkan tentang agama Islam juga. Biasanya sekolah-sekolah Madrasah sebagian besar pelajarannya juga berhubungan dengan agama Islam. Dalam sekolah Madrasah anak juga diajarkan etika dan moral yang harus dilakukan seorang Muslim. Ada banyak hal yang dilakukan orang tua agar anaknya kuat dalam agama sehingga diharapkan anaknya tidak akan mudah terpengaruh oleh perkembangan jaman yang dapat saja membuat anak menjadi anak yang tidak baik.

Dalam bulan-bulan Ramadhan merupakan bulan dimana seorang anak akan mendapatkan ajaran agama yang lebih. Oleh sebab itu orang tua akan mengajarkan puasa kepada si anak sejak anak masih kecil dan menjelaskan mengapa harus berpuasa. Pada bulan-bulan puasa maka di Mesjid setiap harinya akan ada ceramah

${ }^{17}$ Guru mengaji di desa Paya Udang

${ }^{18}$ Ibu Ketua perwiritan perempuan di desan Payah Udang 
dari ustadz dan ini wadah yang digunakan orang tua untuk membimbing anaknya. Setiap anak diajarkan bagaimana menahan lapar dan haus serta berbuat kebaikan kepada orang lain. Biasanya setiap anak sangat senang bila bulan puasa tiba. Untuk memotivasi si anak kadang-kadang orang tua menjanjikan hadiah bagi anak yang penuh puasanya dalam satu hari itu maka anak akan berpuasa untuk mendapatkan hadiah tersebut.

Pada umur empat tahun anak sudah dimasukkan dalam sekolah Playgroup (anak ibu Salmah) agar anak memiliki pergaulan yang baik juga dengan teman-teman sekolahnya. Selain sekolah anak juga diberikan les tambahan misalnya kursus bahasa Inggris untuk menolong pelajarannya disekolah. Orang tua akan lebih ekstra menjaga anak dan memantau ketika anaknya sudah beranjak remaja. Karena pada masa itu anak sudah banyak tahu tentang perkembangan teknologi dan pergaulannya juga sudah lebih luas.

Menurut ibu Juniati anak-anak dulu mengenal lembaga pendidikan hanya Sekolah Dasar (SD), SMP dan SMA. Tidak ada dikenal TK atau pun Play Group, pada masa itu anak-anak langsung disekolahkan ke Sekolah Dasar. Pada masa itu dikenal juga kursus seperti kursus menjahit, untuk membuat anak mengikuti berbagai kursus sangat jarang ini mungkin karena faktor ekonomi juga. zaman anak dahulu sangat jauh perbedaannya dengan anak jaman sekarang. Bila zaman dahulu masih sangat memegang adat-istiadat Tamiang seperti tata krama. Seperti diungkapkan oleh seorang informan bahwa "anak-anak dahulu sangat segan berbicara keraskeras kepada orang yang lebih tua, kemudian anak dulu tidak berani bila berduaan dengan lawan jenisnya tidak seperti anak-anak zaman sekarang yang tidak ada rasa segannya lagi dan sudah dianggap hal biasa”.

\section{Resistensi sebagai Upaya Mempertahankan Pola Asuh Tradisional}

Di Desa Paya Udang dan Desa Sekerak Kanan terlihat bahwa anak yang menetap di desa bersama orang tuanya dan tidak melanjutkan sekolah ke luar kota akan lebih mengerti adat dan menerapkannya di keluarganya, ini dapat dibandingkan anak yang melanjutkan sekolah ke jenjang yang lebih tinggi misalnya kuliah yang banyak tidak mengerti lagi dengan adat Tamiang karena sudah berinteraksi dengan dunia luar. Yang lebih disayangkan lagi, anak-anak yang melanjutkan sekolah ke kota ataupun kuliah keluar daerah sudah tidak pandai lagi berbahasa Tamiang.

Upaya orang tua untuk memperkenalkan dan menerapkan nilai-nilai budaya Tamiang dengan cara mensosialisasikan budaya Tamiang kepada anakanaknya. Salah satu cara mensosialisasikan nilai-nilai budaya biasanya dilakukan orang tua dengan membawa anak ke acara-acara adat seperti ke pesta pernikahan, sunatan atau acara-acara tepung tawar. Upaya ini dilakukan agar anak dapat langsung melihat dan ketika melihat maka orang tua menjelaskan dan terkadang orang lain atau kerabat yang berada disekitar tempat pesta juga menjelaskan arti adat tersebut. Biasanya dijelaskan apa arti pantun yang didengar atau arti tepung tawar dan lainlain.
Tidak hanya pada saat ada acara adat saja orang menjelaskan tetapi juga ketika dirumah orang tua juga mau bercerita. Menurut ibu Salmah ${ }^{19}$ anak zaman sekarang tidak begitu tertarik dengan urusan adat, terkadang kalau orang tua sudah bercerita pun mereka banyak yang tidak berminat. Anak lebih suka cerita tentang hal-hal yang lebih modern. Sehingga ini mengakibatkan sedikit demi sedikit adat itu mulai tidak melekat dalam diri anak-anak Tamiang sekarang. Hal ini terlihat dari hanya beberapa orang saja anak muda yang bisa berpantun di Tamiang. Bila diajarkan mereka menganggap itu sudah tidak zamannya lagi, oleh sebab itu orang yang bisa berpantun dan dikenal banyak orang adalah Toek Yusuf. Bahkan anak-anak pak Yusuf pun tidak ada yang mahir berpantun seperti orang tuanya.

Ketika ada acara-acara yang berkaitan dengan upacara adat tertentu maka Pak Yusuf akan diundang untuk berpantun bahkan tidak hanya di Desa Paya Udang tetapi juga sampai ke daerah Langsa dan terkadang sampai ke Banda Aceh juga. Menurut Pak Yusuf seandainya anak muda sekarang mau belajar maka budaya berpantun pada orang Tamiang akan semakin berkembang dan menjadi kebanggaan bagi orang Tamiang. Tidak hanya berpantun dalam suatu upacara adat selalu terdapat tradisi marhaban. Kegiatan marhaban merupakan suatu upacara yang berkenaan dengan pemberkatan dan permohonan ridho dari Tuhan yang Maha Esa. Marhaban dilakukan dalam upacara perkawinan, mengayun anak, dan juga ketika menyambut tamu kehormatan.

Setiap orang tua memiliki tugas untuk selalu menjelaskan dan menerapkan adat istidat Tamiang sehingga tidak akan terhapus oleh zaman. Apabila tidak ada lagi upaya-upaya mensosialisasikan adat istiadat Tamiang kepada anak-anak, maka para orang tua mengkhawatirkan akan terjadinya pengikisan nilai-nilai budaya Tamiang pada anak-anak.

Saat ini saja ada beberapa hal yang sudah tidak lagi dijalankan oleh para generasi muda. Salah satunya adalah aturan terhadap pantangan-pantangan pada saat masa kehamilan juga tradisi kenduri pada saat perkawianan, kehamilan dan turun tanah. Jenis pantangan yang jarang dilaksanakan pada saat ini adalah sesuatu yang sangat berkaitan dengan nilai-nilai budaya Tamiang dan Islam yaitu mengaji. Dari hasil wawancara yang dilakukan oleh para ibu-ibu yang pernah mengalami masa kehamilan terungkap kebiasaan mengaji pada saat hamil sudah jarang dilaksanakan. Padahal para orang tua dahulu setiap selesai sholat maghrib mereka tetap mengaji. Pergeseran ini terjadi karena mobilitas para ibu-ibu yang saat ini telah banyak melakukan aktivitas di luar rumah. Sehingga ini mengakibatkan waktu luang yang seharusnya digunakan untuk mengaji beralih pada aktivitas yang lain. Sedangkan upacara-upacara pada kenduri sering tidak dilaksanakan mengingat dana juga waktu. Hal ini mengakibatkan ketidak tahuan generasi muda akan resam adat yang ada.

19 Salah satu tokoh wanita Tamiang. Sebagai ketua pelestarian adat Tamiang 
Sikap para orang tua yang melakukan resistensi dan upaya untuk mempertahankan adat istiadat Tamiang ternyata tidak berpengaruh besar trehadap pengimplementasian adat istiadat Tamiang secara mutlak. Hal ini dikarenakan ada sebagaian orang yang menganggap bahwa tradisi yang berkaitan dengan pola asuh tidak lagi sesuai dengan kebutuhan mereka. Ada yang merasa tidak penting tetapi ada juga yang merasa penting. Merasa zaman yang sudah berbeda sehingga sebagian merasa pantangan itu tidaklah penting dilakukan.

Selain perbedaan pandangan pada setiap individu, faktor lain yang mempengaruhi adalah pendidikan, bagi ibu yang memiliki pendidikan yang lebih baik merasa pantangan-pantangan yang harus dilaksanakan pada saat kehamilan karena ia merasa bahwa terkadang ketentuanketentuan yang terdapat dalam nilai-nilai budaya yang berkaitan dengan pola asuh tidak rasional.

Ada orang tua yang marah apabila anaknya meremehkan wejangan-wejangan atau pantanganpantangan yang diberikan orang tua. Cara pandang orang tua untuk melegitimasi adat istiadat tersebut diungkapkan dengan kata-kata sebagai berikut "awas kualat nanti kalau tidak mendengar omongan orang tua" atau biasanya orang tua akan menasehati anaknya kembali dan menceritakan konsekuensi atau akibat yang dialami oleh orang yang melanggar pantangan berdasarkan pengalaman-pengalaman orang tuanya sebelumnya. Ada juga kata-kata yang mengimplementasikan suatu pengharapan agar suatu hal yang buruk tidak terjadi pada dirinya yaitu mengucapkan "jauh-jauhlah segala yang tidak baik".

Dari sini dapat dipahami bahwa faktor yang berperan sebagai resistensi terhadap penerapan dan pelestarian budaya adalah sikap dan peran orang tua yang memberikan pelajaran pemahaman tentang pentingnya adat istiadat dan budaya lokal. Para orang tua ini memberikan pengenalan terhadap budaya ini sejak anakanak masih usia dini.

\section{PENUTUP}

1. Pada hakikatnya, pola asuh etnik Tamiang tidak terlepas dari adat isitiadat dan tradisi lokal yang berlaku di Tamiang. Rangkaian adat dan tradisi dimulai dari adat dan tradisi perkawinan, menjelang kelahiran seperti Resam dan Pantang Pemali, menyambut bayi, nyejapi, turuntanah dan sebagainya merupakan rangkaian yang tidak dapat dipisahkan dari tradisi Tamiang.

Selain itu, faktor hubungan anak dengan orang tua dalam suatu keluarga juga menjadi bagian penting yang berperan dalam pola pengasuhan anak etnik Tamiang. Dalam hal ini, masyarakat etnik Tamiang tidak membedakan gender. Anak laki-laki dan perempuan berkedudukan sama dalam hak, adapaun yang berbeda yaitu dalam hal pembagian kerja.
2. Terjadi pergeseran pola pengasuhan anak pada etnik Tamiang. Akan tetapi perubahan yang terjadi tidak banyak. Perubahan dan pergeseran yang terjadi hanya bersifat pada tataran pola pikir atau cara pandang terhadap pengimplementasian adat istiadat yang dijalankan oleh kelompok etnik Tamiang. Sebagai contoh, ibu-ibu sekarang ini, khususnya para wanita yang menikah muda tidak begitu percaya kepada pantangan-pantangan yang berkaitan dengan masa kehamilan yang menjadi bagian dari kebudayaan mereka, yang salah satunya adalah seperti tidak boleh duduk di tanah tanpa alas, tidak boleh duduk dekat pintu ataupun tidak boleh memotong rambut. Menurut pengakuan mereka bahwa kepercayaan terhadap halhal tersebut diakibatkan oleh pola pikir orang-orang tua mereka dahulu yang masih tradisional. Menurut mereka ketentuan-ketentuan pantangan dan akibatnya bagi calon ibu adalah upaya orang tua untuk membentuk perilaku yang baik kepada ibu dan khususnya calon bayinya. Namun, beberapa ketentuan itu tidak lagi dijalankan sekarang ini, karena terdapat perbedaan pola pikir antara orang tua dan anak-anak mereka yang baru merasakan hamil. Menurut mereka wajar wanita hamil tidak boleh duduk di tanah karena tanah itu kotor. Adapun duduk dekat pintu itu akan membuat orang susah untuk lewat. Menurut ibu-ibu bila mereka tidak memotong rambut, akan terasa panas dan rambut yang panjang sangat merepotkan ketika hamil. Jadi tidak ada hubungannya dengan semua ketakutan-ketakutan yang dikatakan orang tua dahulu.

3. Terjadi resistensi terhadap pola asuh etnik Tamiang. Sebagian masyarakat Tamiang masih mempertahankan pola pengasuhan tradisional berdasarkan adat istiadat yang berlaku seperti adat mulai dari perkawinan, masa kehamilan, serta masa kelahiran. Dalam hal ini, orang tua berperan dalam menerapkan nilai-nilai budaya Tamiang kepada anakanaknya. Sebagian etnik Tamiang masih mengajarkan dan menerapkan nilai-nilai adat tersebut secara sederhana sejak anak di usia dini. Orang tua dan keluarga yang merupakan pranata pertama dalam menanamkan nilai-nilai budaya Tamiang. Apabila si anak tidak mengerti suatu adat maka orang yang pertama sekali ditanyai adalah orang tuanya sendiri. Oleh sebab itu maka orang tua senantiasa memberikan nasehat untuk sebuah acara-acara adat. Selain faktor mempertahankan adat istiadat dengan cara mengenalkan kebudayaan Tamiang kepada anak sejak dini, faktor agama juga menjadi faktor resistensi pola asuh dan kebudayaan lokal. Sebab, sebagian besar masyarakat Tamiang masih menjalankan kewajiban agama dengan baik dan menanamkan nilai- 
nilai agama kepada anak mereka sejak dini. Faktor agama ini menjadi bagian penting dalam upaya resistensi budaya Tamiang, sebab sebagian adat istiadat dan tradisi etnik Tamiang bersesuaian dengan ajaran agama Islam, seperti dalam proses penyambutan kelahiran bayi misalnya. Dalam ajaran Islam, jika lahir anak laki-laki maka diazankan dan bayi perempuan diqamatkan. Demikian juga, adat istiadat Tamiang dalam proses menyambut kelahiran bayi.

Dengan demikian maka dapat disimpulkan bahwa pola pengasuhan anak pada etnik Tamiang pada dasarnya masih berpegang pada adat dan istiadat lokal etnik Tamiang yang diawali dari rangkaian proses seperti pernikahan, kehamilan dan penyambutan kelahiran bayi. Akan tetapi, seiring perkembangan zaman, terjadi pergeseran pola pikir yang berimbas pula pada pola pengasuhan anak. Meskipun demikian, adat isitiadat dan tradisi lokal Tamiang tidak mengalami kepunahan, sebab tejadi proses resistensi akan kebudayaan lokal tersebut melalui pola asuh tradisional sebagaian masyarakat etnik Tamiang dan akulturasi kebudayan dengan agama.

Penelitian ini merekomendasikan beberapa saran diantaranya

1. Penanaman nilai-nilai budaya kepada anak-anak demikian penting dilakukan agar tidak terjadi kepunahan kebudayaan pada generasi mendatang. Oleh karena itu harus dilakukan secara terus menerus pengenalan-pengenalan budaya kepada anak-anak dengan cara yang menyenangkan. Tidak hanya dengan menyampaikan akibat-akibat bagi mereka yang melanggar atau tidak melaksanakan adat istiadat sesuai dengan aturannya.

2. Pola asuh dalam masyarakat terus mengalami perubahan yang mengarah pada dinamika kehidupan. Memang setiap manusia selalu menginginkan penyesuian terhadap dinamisasi kehidupannya. Akan tetapi, sebagai makhluk budaya tidak dapat mengabaikan tata nilai dan norma yang berlaku pada setiap kebudayaan yang berkaitan dengan pola asuh dan penanaman nilainilai budaya kepada anak-anak.

\section{DAFTAR PUSTAKA}

Barth, Fredrik,1988. Kelompok Etnik Dan Batasannya. Jakarta: UI Press

Benedict, Ruth, 1962. Pola-pola Kebudayaan. Jakarta:PT Pustaka Rakyat

Berry. W .Jhon dkk, 1999. Psikologi Antar Budaya, Jakarta: Eralangga
Danandjaja, James. 1989. Kebudayaan Petani Desa Trunyan di Bali. Jakarta: UI Press.

Danny I. Yatim-Irwanto, Kepribadian Keluarga Narkotika, (Jakarta: Arcan, 1991).

EMTAS, 2006. Peradapan Aceh. Banda Aceh:Yayasan Busafat.

Fox, Richard.1978. "Antropologi dan Kota” Berita Antropologi. Nomor 34.

Geerz, Clifford. 1983. Involusi Pertanian. Ahli Bahasa S.Supomo. Jakarta : Bhratara Karya Aksara.

Harley, 2008. Mukim Masa ke Masa.Banda Aceh: JKMA

http://health.kompas.com/read/2011/01/14/11561472/Me nyimak.Pola.Asuh.Anak.di.Negara.Lain\#

http://paradigmaindonesia.wordpress.com/2011/09/17/psi kologi-perkembangan-perspektif-lintas-budayatentang-pola-asuh/

Ihromi, T.O 1987. Pokok-pokok Antropologi Budaya. Jakarta: Gramedia

In Figures Tamiang Aceh, 2006. Aceh Tamiang Dalam Angka. Badan Pusat Statistik, Corporated Wiht

Kartono, 1986. Metodologi Penelitian Pendidikan. Jakarta: PT Bumi Aksara

Koentjaraningrat, 1961. Some Social-Anthropological Observations on Gotong-Rojong Practices in Two Villages of Central Java.Ithaca, NY: Cornell University Press.

Koentjaraningrat, 1997. Manusia Dan Kebudayaan di Indonesia. Jakarta: Djambatan.

Mahmunarrasjid, 1973. Monografi Aceh Timur. Langsa: Set Da Kap Aceh Timur.

Martin, CA \& KK. Colbert (1997). Parenting: a Life Span Perspective. New York: The McGraw-Hill Companies, Inc

Mead, Margaret. 1988. Taruna Samoa (Remaja dan Kehidupan Seks Dalam Kebudayaan Primitif) Suatu Penelitian Antropologi Budaya. Jakarta: Bharatara

Miles, B. Matthew dan Huberman, A. Michael. (1992). Analisis Data Kualitatif Jakarta: UI Press

Moleong, Lexy J. 2010. Metodelogi Penelitian Kualitatif. Bandung: Remaja Rosdakarya Offset.

Muntasir, 2003. Tamiang Dalam Lintasan Sejarah. Banda Aceh: Yayasan Sri Ratu Syafiatun.

Simanjuntak, 2010. Melayu Pesisir Dan Batak Pegunungan (Orientasi Nilai Budaya). Jakarta: Yayasan Obor Indonesia.

Usman Abdul Rani,2003. Sejarah Peradapan Aceh (Suatu Analisis Interaksionis, Integrasi dan Konflik).Jakarta:Yayasan Obor Indonesia. 